\title{
New Perspective for the Philosophy: Re-Construction \& Definition of the New Branches of Philosophy
}

\author{
Refet Ramiz \\ Near East University
}

In this article, author evaluated past/present perspectives about philosophy and branches of philosophy due to historical period, religious perspective, and due to their organized categories/branches or areas. Some types of interactions between some disciplines are given as an example. The purpose of this article is, to solve problems related with philosophy and past branches of philosophy, to define new philosophy perspective in the new system, to define new questions and questioning about philosophy or branches of philosophy, to define new or re-constructed branches of philosophy, to define the relations between the philosophy branches, to define good and/or correct structure of philosophy and branches of philosophy, to extend the definition/limits of philosophy, others. Author considered R-Synthesis as a method for the evaluation of the philosophy and related past branches of philosophy. This R-Synthesis includes general/specific perspective with eight categories, 21-dimensions, and twelve general subjects (with related scope and contents) for the past 12,000 years. It is a kind of synthesis of supernaturalism and naturalism, physics and metaphysics, others. In this article, author expressed 27 possible definitive/certain result cases of the new synthesis and defined the possible formation stages to express new theories, new disciplines, theory of interaction, theory of relation, hybrid theory, and others as constructional and/or complementary theories. These theories are considered for 21 major effective disciplines which are defined for a country and for the world. New philosophy perspective, branches of philosophy, and aims/purposes of R-Philosophy are defined to organize many inquiries about the name, number, and relation between special subject "X" and "philosophy of X" in some manner. This new perspective includes necessary and sufficient number of philosophy branches, and so it limits the number of "philosophy of $\mathrm{X}$ " in the philosophical system. New Era Philosophy is defined with its sub branches, its constructional philosophies, and with its $8 \mathrm{D}$ hybrid philosophy perspective. Ideal Philosophical System is defined with general/specific figure. Some of the new and/or re-constructed branches of philosophy explained with the new defined set of questions, new sub branches and constructional philosophies. Integration of the past/present branches of philosophy into the ideal philosophical system is explained generally. Philosophical interests of the some past philosophers and their relations with the ideal philosophical system expressed with table.

Keywords: philosophy, philosophy of administration, philosophy of information, philosophy of justice, philosophy of politics, philosophy of religion, philosophy of science, philosophy of system, philosophy of electromagnetics

Refet Ramiz, Assist. Professor, Dept. of Electrical and Electronic Eng., Institute of Social Sciences*; Program of Political Science, Program of International Relations, Near East University, North Cyprus, TRNC; main research fields: R-Ideology, Philosophy, Philosophy of Administration, Philosophy of Electromagnetics, Philosophy of History, Philosophy of Information, Philosophy of Justice, Philosophy of Politics, Philosophy of Religion, Philosophy of Science, Constructional Philosophies, Hybrid Philosophy, Branches of Philosophies, Ideal Philosophical System, New Era Philosophy, R-Religion, Religion and Politics, R-Science, Science and Politics, Science and Religion, R-Synthesis. 


\section{Introduction}

In this article, author evaluated meaning of the philosophy, purpose of the philosophy, past/present branches of philosophy generally/specifically. With this respect, metaphysics, ethics, epistemology, ontology, and other branches are evaluated.

In general, the term "philosophy" is defined as "love of wisdom." In a broad sense, philosophy is defined as an activity "people undertake" when they seek to understand fundamental "truths" about themselves, the world in which they live, and their "relationships" to the world and to each other. This definition is meaningful, however, it is limited by some experts because of "love," "activity," "people," and the "world" relationship considered between people to people, between people to world.

Contrary to popular belief, faith is defined as critical in every philosophy. Contrary to popular teaching, the theistic philosophies required no more faith than the naturalistic philosophies. Some authors argued that it takes a great deal more faith to believe in the spontaneous generation of life and the randomness of all nature than it does to accept the theistic doctrines of Creator and creation. The foundation of philosophy is defined as the key of a person's entire worldview. Due to some experts, people must choose between supernaturalism (someone is responsible for all that people see) or naturalism (all that people see is responsible for itself). It is expressed by some experts that people choice will dictate their philosophical presuppositions across every area of their life.

There are three general questions considered by some experts about philosophy, aims of the philosophy, its boundaries, and its methods: (1) What is philosophy? (2) What is, or what should be, the point of philosophy? (3) How should one do philosophy? Those questions resolved into a host of more specific perspective, some of which are as follows: (a) Is philosophy a process or a product? (b) What kind of knowledge can philosophy attain? (c) How should one understand philosophical disagreement? (d) Is philosophy historical in some special or deep way? (e) Should philosophy make human being better people? (f) Is philosophy political? (g) What method(s) and types of evidence suit philosophy? (h) How should philosophy be written? Author gave answer to these questions with the new defined philosophy perspective in the following sections generally/specifically.

Author noticed that some past/present ideologies, religions, sciences, branches of philosophy do not include and/or accept one, or some, or all the other disciplines or sub-inner disciplines of them. Also it is noticed that the content or purpose of the some philosophy branches is defined incorrectly.

Author made the R-Synthesis of supernaturalism and naturalism in some manner, where $27(+)$ definitive/certain result cases are applied. As result of this R-Synthesis author defined new perspective of philosophy and New Era Philosophy.

It is important to understand the meaning of the words, their definitions, and the related contents in good and/or correct way (Ogden and Richards 1956; others). With this respect, author considered most of the subjects/words related with the philosophy, science, and other disciplines during his synthesis. As an example, the term "social" (Social, 2016), which is referred to a characteristic of living organisms as applied to populations of humans and other animals, can be considered. It is proposed that the word "social" always refers to the "interaction" of organisms with other organisms and to their collective co-existence, irrespective of whether they are aware of it or not, and irrespective of whether this "interaction" is voluntary or involuntary. One can ask if this social request, is for establishing a relation, or for monetary benefits, or is a part of enjoying together, or other. Author explained this in the following sections. Another example is about the word 
"knowledge." Knowledge is defined by some experts as of five kinds: (i) sensory knowledge, (ii) scriptural knowledge, (iii) clairvoyance, (iv) telepathy, and (v) omniscience.

Another good example is about some scientific words/subjects given as follows. Some experts can think that one science discipline is defined first, so it is the basic of all, and all of the others are/can be derived from this one science discipline. Author noticed that biology*, chemistry*, electromagnetic*, information*, mathematics*, physics* were there, before they were invented/discovered/defined by some human beings, and probably their names were different. Author proposed that the name of these disciplines are "science/law of living forms," "science/law of plasma, condensate, solid, liquid, gas object," "science/law of seen and/or unseen energy forms," "science/law of knowledge," "science/law of numbers, size, shape, volume, distance/length, direction, etc.," and "science/law of motion and mass" respectively. Here, law can be considered as macro law, functional law, micro law in some manner.

Author defined new words about philosophy and branches of philosophy, and also made new or re-constructed definitions about the philosophy.

The purpose of this article is: (i) to define systematic solution for the conflicts, problems, confusions related with philosophy, and past branches of philosophy, (ii) to define and express the importance and place of new philosophy perspective in the new system, (iii) to define new questions and questioning about philosophy or branches of philosophy, (iv) to define new or re-constructed branches of philosophy, (v) to define the relations between the philosophy branches, (vi) to define good and/or correct structure of philosophy and branches of philosophy, (vii) to extend the definition/limits of philosophy, (viii) to make correction about the meanings of some philosophical definitions, and (ix) others.

New philosophy perspective defined to organize many inquiries about the name, number, and relation between special subject " $X$ " and "philosophy of X" in some manner. This new perspective includes necessary and sufficient number of philosophy branches, and so it limits the number of "philosophy of X" in the philosophical system.

"Information" must be use for good and/or correct purposes. Author defined good and/or correct perspective that must be behind the definition of philosophy and branches of philosophy.

It is important to note that if one person considers "every" new founding as a parameter of changing the past history and/or future history, it means he/she does not understand what is the meaning of the synthesis, or the synthesis they considered is limited dimension, just like some scientists, philosopher offered, due to their limited philosophy perspective until now. A person who is a side to "one" science, philosophy, religion, or ideology discipline can do meaningful or good founding, definition, parallel to another person in another one discipline. In that case, there may be several questions that could be asked; is the science, philosophy for your personal needs, is the science, philosophy for community needs, etc. or a scientist, philosopher is going to use the science, philosophy and community for his/her personal needs because of his/her person nature (Ramiz 2015; Ramiz, January 2016). With this respect, the purpose of philosophy, or in other manner branches of philosophy is re-evaluated by the author, and new perspective for philosophy, and philosophy branches are defined. Author considered R-Synthesis as a method for the evaluation of the philosophy, and related branches of philosophy defined in the past. It is a kind of synthesis of supernaturalism (someone is responsible for all that people see) or naturalism (all that people see is responsible for itself), a kind of synthesis of physical science and non-physical science, a kind of synthesis of physics and metaphysics, science and non-science, politics and non-politics. General and specific contents of the new synthesis expressed in the following sections. 
This article includes and expresses the specific scientific/philosophical perspective of the synthesis of the author. Author defined ideological, lawful, political, religious, scientific, etc., perspective of the synthesis in other work generally/specifically (Ramiz, 2015; Ramiz, 2016). Here the cited works of "Ramiz, R." given in the last part of this article, and (Ramiz, yyyy) given here are used to express that they are written by the author.

Here "R-abcde...xyz" are used to express that they are considered by the author, and they are new defined, or re-constructed from the past/present ones, or modified, or used with the same name and arranged due to all 21 dimensions of the synthesis (Ramiz, March 2016), and due to 27 (+) definitive result cases of the synthesis in general manner. With this respect, New Perspective for the Philosophy, and Re-construction \& Definition of the New Branches of Philosophy are defined.

R-Synthesis includes general/specific perspective with eight categories, 21-dimensions, and 12 general subjects (with related scope and contents) for the past 12,000 years. With this respect, the method considered for this new synthesis includes all subjects, and it is not necessary to apply the following evaluation process triple of “... going past, then come to present, propose something for future, then go to past, and come to present, and propose something for future..."

Author defined R-Ideology, R-Information, R-Justice, R-Philosophy, R-Religion, R-Science, R-System, and others as complementary to each other, and they are considered as definitive because of the 27 definitive result cases of the new synthesis, also because of the basic components of science, philosophy, religion, ideology as generally/specifically explained in the following sections.

In this article, the new synthesis is defined in the second section, as a method for the evaluation of the all subjects and for the solution of the related philosophical problems. With this respect, author explained: (i) the general perspective considered for the new synthesis, (ii) the scope/content of the subjects considered for the new synthesis, (iii) the dimension of the new synthesis, and (iv) definitive/certain result cases of the new synthesis. In the third section, past/present perspectives about philosophy and branches of philosophy are expressed. Author explained philosophy, generally/specifically, due to historical period, due to religious perspective, due to its organized categories/branches or areas, and some of the interactions considered between the disciplines by some experts. In the fourth section, constructional and/or complementary theories are defined. Theory of interaction, theory of relation, and hybrid theory explained. In the fifth section, major effective disciplines for a country and for the world are defined. In the sixth section, new perspective of philosophy is defined. In the seventh section, New Era Philosophy, Ideal Philosophical System and new and/or re-constructed branches of philosophy are defined. In the eighth section, integration of the past/present branches of philosophy into the ideal philosophical system is generally expressed. In the ninth section, philosophical interests of the some past philosophers are given. In the tenth section, conclusion is given. Some works, studies which are cited in the work are given at the last section.

Each of the letters, words, sentences, table, figure, definitions, comparison, and others within this article is defined by the author generally/specifically, and each of them expresses some specific subjects but is also considered as complementary of other subjects.

\section{The New Synthesis}

In this section, the author explained the new synthesis generally/specifically. With this respect, general perspectives considered for the synthesis, scope/content of the subjects, dimension of the new synthesis and definitive/certain result cases of the new synthesis are generally/specifically explained respectively. 


\subsection{General Perspectives Considered for the New Synthesis}

Author defined that, a subject and/or an event can be evaluated by considering the following eight category of perspectives in general (in alphabetic order):

(1) Perspective due to its applied person/founder: (a) due to his basic senses; (b) due to his ethics; (c) due to his experiences; (d) due to his functional position level; (e) due to his ideal political construction; (f) due to his R-Ideology; (g) due to his information level; (h) due to his theory; (i) due to his R-Philosophy; (j) due to his principles; (k) due to his R-Religion; (l) due to his R-Sciences; (m) due to his sense of justice; (n) due to his synthesis; (o) due to his R-Values, and (p) R-Hybrid,

(2) Perspective due to dimension considered,

(3) Perspective due to the disciplines/sub disciplines considered: (a) academic perspective; (b) administration perspective; (c) alternative medicine perspective; (d) central perspective; (e) commercial perspective; (f) community perspective; (g) company perspective; (h) democratic perspective; (i) diplomatic perspective; (j) doctor perspective; (k) economic perspective; (l) educational perspective; (m) ethnic perspective; (n) financial perspective; (o) health perspective; (p) ideological perspective; (q) industrial perspective; (r) judgment perspective; (s) justice perspective; (t) lawful perspective; (u) medical perspective; (v) military perspective; (w) monetarist perspective; (x) mythological perspective; (y) national perspective; $(\mathrm{z})$ over politic perspective; (aa) personal perspective; (ab) philosophical perspective; (ac) political perspective; (ad) producer/manufacturer perspective; (ae) public perspective; (af) religious perspective; (ag) scientific perspective; (ah) security perspective; (ai) separative perspective; (aj) social perspective; (ak) stability perspective; (al) standardization perspective; (am) system perspective; (an) unionize perspective; (ao) R-Hybrid perspective,

(4) Perspective due to formality considered: (a) non-official perspective; (b) official perspective; (c) R-Hybrid,

(5) Perspective due to geographical structure considered: (a) territory based; (b) local; (c) country based; (d) regional; (e) transcontinental; (f) worldwide; and (g) R-universal/cosmos,

(6) Perspective due to number and/or size considered,

(7) Perspective due to number of subjects considered: 37 subjects of services,

(8) Perspective due to size, content, and sensitivity of subject(s) considered: (a) micro; (b) functional; (c) macro; and (d) R-Hybrid.

Author considered all of these eight category perspectives, and all of their sub cases together and separately, generally and specifically, for the new synthesis, where this perspective can be named as R-Hybrid-8C-P.

\subsection{Scope, Period and Content of the Subjects Considered for the New Synthesis}

Author made the synthesis by considering the following subjects, related contents and the related interactions together and separately, and generally/specifically (in alphabetic order): (1) Ethnic origins (Ethnic Groups 2015; n.d.); nearly 1,600 ethnic origin around the world, (2) Federations; 27 federations (Federation, 2016), (3) Ideology (Political Ideologies, 2010; Ideology, October 2015); (4) Mythologies: (a) more than 130 regional mythologies (List of Mythologies June 2015), (b) more than 301 kind of deities, (c) more than 44 subjects of deities, (d) more than 44 cultural deities, (5) Organizations, (6) Philosophy: (a) 680 philosophies (by country; by main branches; by sub branches; by sub fields; by religious; by period; by subjects) (List of 
Philosophies, March 2016; Philosophy, 2015 \& 2016; List of Philosophers, June 2016), (b) philosophy of religion; more than 36 theories of religion, 87 philosophers of religion and their professional interests (List of Philosophers of Religion, August 2015; Philosophy of Religion, October 2015), (c) philosophy of politics; 48 political philosophers and their works/professional interests (Political Philosophers, August 2015; Influential Political Philosophers, August 2015; Philosophy of Politics, October 2015), (d) philosophy of science; 55 philosophers of science and their works/professional interests (List of Philosophers of Science, August 2015; Philosophers of Science, August 2015; Philosophy of Science, 2015 \& 2016; Branch of Philosophy of Science, March 2016), (e) philosophy of history; 42 thinkers/philosophers of History and their works/professional interests (Philosophy of History, June 2015; Philosophers of History, August 2015), (f) philosophy of law; 20 philosophers of law and their works/professional interests (Philosophy of Law, August 2015; Notable Philosophers of Law, August 2015), (g) philosophy of mind; 132 thinkers/philosophers of mind and their works/professional interests (List of Philosophers of Mind, August 2015; Philosophers of Mind, August 2015; Philosophy of Mind, August 2015), (h) ethics, (i) epistemology, (j) metaphysics, (k) logic, (l) aesthetics, (m) ontology, (n) meta-philosophy (Meta-philosophy, March 2016), (o) 33 Lists of philosophers by language, nationality, religion, or region, (7) Politics: (a) political ideology spectrums (Political Spectrum, 2015), (b) political/non-political administration systems (Political Systems, October 2015), (c) politic power sources, (d) politic power structures, (e) public administrations, (f) all political ideologies (Political Ideologies, October 2015; List of Political Ideologies, May 2010; Political History, June 2015), (g) all party systems (Party System, 2015), (h) organs of government, (8) Religions; 168 religions, sects, denominations (Religion, October 2015; List of Religions, August 2015; Religion and Mythology, February 2016; History of Religions, May 2010; Political Religion, February 2016), (9) Religious books and texts, classics, teaching books, doctrines, etc. (Religious Books, 2015), (10) Sciences: (a) 620 science branches (Science, May 2015; History of Science, May 2015; Religious Science, March 2016), (b) some pioneer scientists and their works, professional interests, (11) Interaction; between the all these nine disciplines and related subjects (Science and Religion, March 2016; Religion and Science, 2015 \& 2016; Religion and Politics, 2015 \& 2016), (12) Evaluation period; for the last 12,000 years (Gülaltay 2005; History of Philosophy, 2016; History of Religions, 2010; History of Science, 2015; Bucaille 1973; Yücel 1985; others), and (13) personal and other different experiences and /or references (Ramiz March 2016).

\subsection{Dimension of the New Synthesis}

There are 21 dimensions of the R-Synthesis considered by the author, and they are given here as follows (in alphabetic order): (1) R-Administration, (2) R-Basic senses (Ramiz 2016), (3) R-Continuity, (4) R-Energy, (5) R-Geography (space), (6) R-Hybrid, (7) R-Ideology, (8) R-Integration, (9) R-Living forms, (10) R-Organization, (11) R-Philosophy, (12) R-Priority, (13) R-Progression, (14) R-Religion, (15) R-Science, (16) R-Sense of justice, (17) R-Subjects of services, (18) R-Systems, (19) R-time, (20) R-Transformation, and (21) R-Values.

Some of these dimensions are expressed here shortly thourgh their relations with the philosophical perspective; some others are described in other works generally/specifically (Ramiz 2015; Ramiz 2016). Some others will be explained in the future works with more details. 


\subsection{Definitive/Certain Result Cases of the New Synthesis}

Author considered 21 dimensions of the R-synthesis to evaluate the subjects given in previous section, and made R-synthesis based on both "theoretical and experienced" information. As a result of the new synthesis, author defined following $27(+)$ possible definitive/certain result cases of the synthesis (in alphabetic order): (1) to add some subjects; (2) to balance some subjects; (3) to change the priority of some subjects; (4) to consider common subjects; (5) to consider transition for some subjects; (6) to converge to some subjects; (7) to define all subjects under one framework; (8) to define new subjects; (9) to educate; (10) to eliminate some subjects; (11) to fix some subjects; (12) to have some waving about some subjects; (13) to improve values of some subjects; (14) to integrate all subjects; (15) judgment; (16) to keep (protect) some subjects; (17) to modify some subjects; (18) to propose progression for all subjects; (19) to put rules; (20) to re-construct some subjects; (21) to re-define some subjects; (22) to remove some subjects but put new subjects instead immediately; (23) revolution; (24) to separate some subjects; (25) to train; (26) to unify some subjects; (27) to unite some subjects in upper phase; (28) to hybrid; (29) others.

Author considered the following $27(+)$ result cases for the new synthesis, and applied them for the design and/or re-construction of the new local/regional/worldwide systems, and for the definition and/or re-construction of the all related subjects/disciplines/dimensions, and to all new theories he defined.

With this respect, here, all the past/present definition of the philosophy, philosophy branches, related sciences, branches of sciences are evaluated generally/specifically, and they are integrated into the new philosophy framework by applying 27 (+) result cases of the synthesis for each philosophy discipline through the new philosophy perspective of the author.

The new philosophy framework defined here is a unique structure which collects past, present, and all other types of possible future arrangements, under one framework through new defined R-values and other subjects expressed below (Ramiz 2015; Ramiz 2016).

\section{Past/Present Perspectives about Philosophy and Branches of Philosophy}

Author evaluated most of the theories/perspectives of some experts, philosophers about the meaning and definition of the philosophy, and its branches generally/specifically. Some of them are given below as different cases (List of Philosophies, March 2016; others).

\subsection{Philosophy due to Historical Period}

Author divided the Philosophy into the following "historical periods" as follows by considering the general perspectives considered for the New Synthesis in section 2 above: (1) Ancient philosophy; Egypt and Babylon, Ancient Chinese, Ancient Greco-Roman, Ancient Indian, Ancient Persian, (2) 5th-16th centuries; Medieval Europe, Renaissance, East Asia, India, Middle East, Mesoamerica, Africa, (3) Early Modern and Modern (17th-18th centuries), 19th century, 20th century, (4) New Era Philosophy (future).

\subsection{Philosophy due to Religious Perspective}

Religious philosophy is defined by some experts in the past as philosophical thinking that is inspired and directed by a past/present particular religion. Due to this perspective, it can be done objectively, but may also be done as a persuasion tool by believers in that faith. Author divided philosophies into the following different branches by considering past and new religious perspectives for each religion such as (in alphabetic order): (1) 
Buddhist philosophy, (2) Christian philosophy, (3) Hindu philosophy, (4) Islamic philosophy, (5) Jain philosophy, (6) Jewish philosophy, (7) R-Religion philosophy, and (8) Sikh philosophy.

\subsection{Philosophy due to Its Organized Categories, Branches, or Areas}

Some of the categorizing about the philosophy, which are expressed by some thinkers/philosophers until now, are given below as cases due to different types of references. This is also important to express how the philosophy is evaluated by some of the academic, scientific, religious, encyclopedic and other perspectives.

\begin{tabular}{|c|c|}
\hline Case-1: & $\begin{array}{l}\text { Some people in the history organized the philosophy into "five basic categories:" metaphysics, epistemology and } \\
\text { logic, ethics, politics, aesthetics. (Philosophy, FSU, 2016) }\end{array}$ \\
\hline Case-2: & $\begin{array}{l}\text { Philosophy “divided into sub fields:" epistemology, logic, metaphysics, ethics, political philosophy, aesthetics, and } 14 \\
\text { specialized branches. (Philosophy, Wikipedia, October 2016) }\end{array}$ \\
\hline Case-3: & $\begin{array}{l}\text { Philosophy "divided into major areas of study" as: metaphysics, epistemology, ethics, logic. (Philosophy, Space and } \\
\text { Motion, 2016) }\end{array}$ \\
\hline Case-4: & $\begin{array}{l}\text { "Categories" of Philosophy: epistemology, ethics, logic, philosophy of anthropology, philosophy of history, philosophy } \\
\text { of language, philosophy of law, philosophy of love, philosophy of religion, philosophy of sexuality, philosophy of war, } \\
\text { political philosophy, philosophy of science, philosophy of mind. (Philosophy, Internet Encyclopedia, March 2016) }\end{array}$ \\
\hline Case-5: & $\begin{array}{l}\text { It is considered that there are "five primary categories or branches" within philosophy: epistemology, metaphysics, } \\
\text { ethics, logic, aesthetics. (Branches of Philosophy. In Theological Studies, March 2016) }\end{array}$ \\
\hline Case-6: & $\begin{array}{l}\text { Philosophy can be "divided into five branches:" metaphysics, epistemology, ethics, politics, esthetics. (Branches of } \\
\text { Philosophy, In Importance of Philosophy, March 2016) }\end{array}$ \\
\hline Case-7: & $\begin{array}{l}\text { "Branches" of philosophy are: epistemology, metaphysics, logic, ethics, + other branches. } \\
\text { (Branches of Philosophy, In Wikibooks, March 2016) }\end{array}$ \\
\hline Case-8: & $\begin{array}{l}\text { Philosophy can "divide into inter-related subjects:" (a) metaphysics-first philosophy, natural theology, (b) } \\
\text { epistemology, (c) axiology - ethics, aesthetics, social, (d) logic, (e) natural philosophy, (f) The Philosophy of A, where } \\
\text { the value of the variable A can be any subject -8 philosophy defined under these perspective. (Philosophy, In } \\
\text { Roangelo; Categories of Philosophy, In Ro angelo, March 2016) }\end{array}$ \\
\hline Case-9: & $\begin{array}{l}\text { Philosophy "by branches and related doctrines:" epistemology, metaphysics, logic, ethics, political philosophy, } \\
\text { aesthetics }+ \text { other branches. (Philosophy, In Philosophy Basics, March 2016) }\end{array}$ \\
\hline Case-10: & $\begin{array}{l}\text { "Branches" of philosophy are: metaphysics, epistemology, politics, ethics, esthetics. } \\
\text { (Branches of Philosophy, In Metaphysics for Life, March 2016) }\end{array}$ \\
\hline Case-11: & $\begin{array}{l}\text { "Areas" of philosophy are: aesthetics, ethics, epistemology, logic, metaphysics, philosophy of science, political } \\
\text { philosophy, African philosophy, existentialism, feminist philosophy, history of philosophy, philosophy of language, } \\
\text { philosophy of mind, philosophy of religion. (Philosophy. In Learnnc. March 2016) }\end{array}$ \\
\hline Case-12: & $\begin{array}{l}\text { It is defined that there are "branches" of philosophy as: philosophy of information, philosophy of economics, } \\
\text { philosophy of neuroscience, philosophy of science, philosophy of mathematics, philosophy of biology, philosophy of } \\
\text { psychiatry, philosophy of religion, philosophy of technology, philosophy of liberation, philosophy of education, } \\
\text { philosophy of music, philosophy of statistics, philosophy of law, philosophy of history, philosophy of childhood, } \\
\text { philosophy of film, philosophy of statistical mechanics, philosophy of linguistics, philosophy of humor, philosophy of } \\
\text { dance, philosophy of chemistry, philosophy of political, philosophy of mind, philosophy of computer science, } \\
\text { philosophy of language, legal philosophy, metaphysics, philosophy of architecture, philosophy of physics, philosophy } \\
\text { of digital art. (Information, In Stanford University. March 2016) }\end{array}$ \\
\hline Case-13: & $\begin{array}{l}\text { There are four "main traditional branches" of philosophy namely: axiology (ethics and aesthetics), epistemology, } \\
\text { metaphysics, and logic. }\end{array}$ \\
\hline Case-14: & There are four "branches" of philosophy: ethics, epistemology, logic, metaphysics. \\
\hline Case-15: & $\begin{array}{l}\text { There are three "branches" of philosophy: metaphysics, epistemology, axiology. (Branches of Philosophy. In Slide } \\
\text { Share. March 2016) }\end{array}$ \\
\hline Case 16: & $\begin{array}{l}\text { There are three "areas" of philosophy: (a) theory of reality —ontology \& metaphysics, (b) theory of knowledge- } \\
\text { epistemology, (c) theory of value - axiology. }\end{array}$ \\
\hline Case-17: & $\begin{array}{l}\text { The "main branches" of philosophy are: metaphysics, ethics, logic, epistemology, aesthetics. The "sub branches" of } \\
\text { these main branches are: philosophy of science, philosophy of language, philosophy of religion, political philosophy, } \\
\text { and philosophy of mind. (Philosophy. In Conservapedia) }\end{array}$ \\
\hline Case-18: & $\begin{array}{l}\text { "Topics" under the title philosophy are: logic, metaphysics, epistemology, ethics, political philosophy, philosophy of } \\
\text { science, aesthetics. }\end{array}$ \\
\hline Case-19: & $\begin{array}{l}\text { Traditional philosophy "branches" are: epistemology, metaphysics, logic. (Philosophy. In Philosophy Religion, March } \\
\text { 2016) }\end{array}$ \\
\hline Case-20: & "Branches" of philosophy are: metaphysics, epistemology, ethics, politics, aesthetics. \\
\hline
\end{tabular}




\begin{tabular}{|l|l|}
\hline Case-21: & $\begin{array}{l}\text { "Branches" of philosophy are: logic \& philosophy of language, ontology and metaphysics, epistemology and } \\
\text { methodology, ethics. }\end{array}$ \\
\hline Case-22: & "Branches" of philosophy are: metaphysics, ethics, epistemology, logic, aesthetics, philosophy of politics. \\
\hline Case-23: & Metaphysics is defined as a philosophy, and its branches are: theology, ontology, cosmology. \\
\hline Case-24: & Branches of metaphysics are: space and time, ontology, identity, others. \\
\hline Case-25: & There are metaphysics, epistemology, axiology. And all the "philosophies of xxx" are proposed under metaphysics. \\
\hline Case-26: & It is considered that followings are "included" in the philosophy: logic, epistemology, value theory, metaphysics. \\
\hline Case-27: & $\begin{array}{l}\text { "Branches" of philosophy are: ethics, metaphysics, logic, political philosophy, philosophy of language, philosophy of } \\
\text { religion, philosophy of science, Meta-philosophy, philosophy of law, philosophy of education, philosophy of history, } \\
\text { philosophy of mathematics. } \\
\text { "Fields" of philosophy are proposed as: ethics (sub types of ethics), metaphysics (ontology, philosophy of mind, } \\
\text { philosophy of space and time, philosophy of action). (Outline of Philosophy. In Wikipedia. March 2016) }\end{array}$ \\
\hline Case 28: & Others. \\
\hline
\end{tabular}

The five general branches of philosophy, which are given in the above cases and are considered as traditional branches of philosophy, are shortly explained below (in alphabetic order).

(a) Aesthetics:

Perspective of the Study; It is defined as a branch of philosophy dealing with the nature of art, beauty, enjoyment, perception, and taste, with the creation and appreciation of beauty. It is defined more scientifically as the study of sensory or sensori-emotional values, sometimes called judgments of sentiment and taste. More broadly, scholars in the field define aesthetics as "critical reflection on art, culture and nature." More specific aesthetic theory, often with practical implications relating to a particular branch of the arts, is divided into areas of aesthetics such as art theory, literary theory, film theory, and music theory. An example from art theory is given as aesthetic theory and as a set of principles underlying the work of a particular artist or artistic movement. It is expressed as the study of art and beauty as concepts as well as how people ought to evaluate potential instances of beauty and artistic creation. It is also defined as the analysis of the nature and experience of art and beauty (Aesthetics, 2016; Branches of Philosophy, In Theological Studies, March 2016; Philosophy, In Learnnc, March 2016).

(b) Epistemology:

Perspective of the Study; It is expressed as the study about the debate on four areas: (1) the philosophical analysis of the nature of knowledge and how it relates to such concepts as truth, belief, and justification, (2) various problems of skepticism, (3) the sources and scope of knowledge and justified belief, and (4) the criteria for knowledge and justification. It considered the theory of knowledge, especially with regard to its methods, validity, and scope, and the distinction between justified belief and opinion. Epistemology is defined as the study of the nature and scope of knowledge and justified belief. It analyzes how the nature of knowledge relates to similar notions such as truth, belief and justification. It also deals with the means of production of knowledge, as well as skepticism about different knowledge claims. It is essentially about issues having to do with the creation and dissemination of knowledge in particular areas of inquiry. Epistemology is considered by some experts as one of the "core areas" of philosophy. It is concerned with the nature, sources and limits of knowledge (Epistemology, March 2016; Outline of Philosophy, March 2016; others).

(c) Ethics:

Perspective of the Study; It considered the analysis of the nature of morality and morals. It is the study of correct action. It deals with the question of how people ought to act with regard to themselves, other people, and the world, values, and decision making process. It is the study of action, study of "moral value," "right and wrong." It involved with placing value to personal actions, decisions, and relations. The study of ethics often 
concerns what we ought to do and what it would be best to do. In struggling with this issue, larger questions about what is good and right arise. Ethics or "moral philosophy," is defined as the branch of axiology that studies good and bad, right and wrong. The primary investigation of ethics or morality is given as the best way to live. Ethics or moral philosophy is expressed as the branch of philosophy that involves systematizing, defending, and recommending concepts of right and wrong conduct. The branch of philosophy axiology comprises the sub-branches of ethics and aesthetics, each concerned with values. It is defined as the study of difference between morally right and wrong actions, values, or institutions (Ethics, 2016; Philosophy, In Learnnc, March 2016; Branches of Philosophy, In Importance of Philosophy, March 2016; others).

(d) Logic:

Perspective of the Study; It is defined as the analysis of terms, propositions, and the principles of reasoning. It is the rules (both formal and informal) of reason. It is study of "abstract symbolic reasoning." It resembles mathematics in that it works from axioms and seeks to prove theorems, but it differs in that it does not involve numbers. It is the study of "right reasoning." It is the tool philosophers use to study other philosophical categories. Good logic includes the use of good thinking skills and the avoidance of logic fallacies. It is the study of the nature and structure of arguments. It is the study of reasoning and argument. An argument is " $a$ connected series of statements intended to establish a proposition." The connected series of statements are called "premises," and the proposition being established is called the conclusion. Because sound reasoning is an essential element of all sciences*, social sciences* (Branches of Social Science, 2016; Social Science, 2015 \& 2016), and humanities disciplines*, logic is classified as a formal science*. Due to some references, there is no universal agreement as to the exact scope and subject matter of logic, but it has traditionally included the classification of arguments, the systematic exposition of the "logical form" common to all valid arguments, and the study of fallacies and paradoxes. Historically, logic has been studied in philosophy (since ancient times) and mathematics (since the mid-1800s), and recently logic has been studied in computer science, linguistics, psychology, and other fields. Logic and the philosophy of language* are considered closely related. Logic studies the constitution of good or bad reasoning, determination of piece of reasoning as good or bad (Logic, 2016; Branches of Philosophy, March 2016).

(e) Metaphysics:

Perspective of the Study; It is defined as the study of the most general features of reality, such as existence, time, the relationship between mind and body, objects and their properties, wholes and their parts, events, processes, and causation. It is expressed as the study of the nature of reality, of what exists in the world, what it is like, and how it is ordered. It is the study of "reality" that is beyond the scientific or mathematical realms. The term "metaphysics" itself literally means "beyond the physical." It is the study of existence and the nature of existence. It is study of what exists and the structure within which the objects that make up the world operate. This included the concepts of being, existence, immortality, God, spiritual beings, time, identity, consciousness, cause, essence, space, constancy etc., in general manner. It is the analysis of concepts, which transcend physical science, including the philosophy of mind*. It is the study of nature of a person, meaning of truth, existence of God, existence of mind, the reaction of mind and body, effect of one event to other. It discusses the existence of God, the soul, and the afterlife. It evaluates the meaning of time, nature of reality. It is the study of the world in its entirety, and the study of being. Traditional branches of metaphysics include following sub fields: (a) ontology, (b) Philosophy of mind*, (c) philosophy of space and time*, (d) philosophy of action* (Metaphysics, 2016; Philosophy, March 2016). 
It is expressed that, this organization/system of the philosophy with five general categories given above is partly used in western philosophy until now, but the notion of philosophy has become more restricted to the key issues of being, knowledge, and ethics due to these experts/thinkers. At the same time, there has been a huge increase about the number of expressing of "philosophy of abcde," meaning a philosophical inquiry into just about any field, as partly mentioned above cases. There are many places, where these field subjects overlapped, and there are many philosophical ideas that cannot be placed neatly into only one of these five categories of philosophy until now. Author noticed that one of the reasons for this is because some/most/all of the experts did not have necessary and sufficient theoretical and experienced information about all subjects generally/specifically.

Author evaluated 680 philosophies around the world through the R-Synthesis and defined new philosophy perspective for the world to solve the problems in philosophical perspective (R-Philosophy). Here, as part of the R-synthesis, and as complementary part of the R-Philosophy, author defined necessary and sufficient number of philosophy branches, where each possible philosophical idea is placed neatly into these new or re-constructed branches of philosophy (R-Philosophy). More specific information is given in the following sections.

Many academic disciplines have also generated philosophical inquiry. The "relationship" between " $\mathrm{X}$ " and the "philosophy of X" is debated. Richard Feynman $(1950 ; 1964 ; 2016)$ argued that the philosophy of a topic is irrelevant to the primary study of a topic, saying that "philosophy of science* is as useful to scientists as ornithology is to birds." Curtis White, by contrast, argued that philosophical tools are essential to humanities*, sciences*, and social sciences*.

When the questioning of each branch of philosophy is evaluated, it is possible to notice the possible interactions, and so relations between each branch of philosophy. Those possible interactions are evaluated due to 27 definitive result cases of R-Synthesis, and the good and/or correct relations between the branches are defined accordingly.

\subsection{Some of the Interactions Considered between the Disciplines by Some Experts}

As a result of the synthesis, the author noticed that, interaction is one of the subjects, and also a way of evaluation of some problems to determine, to solve and to define the possible solutions for these problems in good and/or correct way. The author considered necessary and sufficient types of interactions about the subjects included within the R-Synthesis and defined the solutions accordingly.

With this respect, some subjects, which are mentioned/defined by some scholars or experts by considering interaction, are given below as examples. In general manner, these interactions are categorized as ideological interactions, philosophical interactions, political interactions, religious interactions, scientific interactions, social interactions, and others (in alphabetic order) to guide some people to understand some past/present problems related with these interactions. Good and/or correct definition of the interaction perspective and the solution perspective are given in the following section.

It is possible to consider following scientific subjects defined by some people to understand the possible scientific interactions (in alphabetic order): biology*, for "study of life and living organisms, including their structure, function, growth, evolution, distribution, identification and taxonomy;" chemistry*, for "study of composition, structure, properties and change of objects (matters);" electromagnetism*, for "study of the electromagnetic force, an as a type of physical interaction that occurs between electrically charged particles;" 
mathematics*, for "study of quantity, numbers, structure, space, and change;" physics*, for "study of object (matter) and its motion through space and time, along with related energy and force."

On the other hand, some people defined the matter (due to their scientific perspective) as composed of atoms, and excluded other energy phenomena such as light or sound. This concept of matter is generalized by some people from atoms to include any objects having mass even when at rest, but due to some experts this is ill-defined because an object's mass can arise from its (possibly mass less) constituents' motion and interaction energies.

Beside this, it is expressed that, the electromagnetic force "usually" shows electromagnetic fields, such as electric fields, magnetic fields, and light. Here, the electromagnetic force is defined by some experts as one of the four fundamental interactions in nature. The other three fundamental interactions are proposed as strong interaction, weak interaction, and gravitational interaction.

However, it is important to note the difference between electromagnetism, electromagnetic force, electromagnetic fields, electromagnetic induction, electromagnetic waves, electromagnetic energy, and electromagnetic interaction. Hans Christian Ørsted (2016) discovered the "interaction" and then "relationship" between electric currents creates magnetic fields (interaction between electricity and magnetism). Ampere discovered the "interaction" and "relationship" about magnetic forces between current-carrying conductors, also "interaction" between electric charges and currents (interaction between electricity and magnetism). Faraday made research on the magnetic field around a conductor carrying a direct current, also "established" that magnetism could "affect" rays of light and that there was an underlying "relationship" between the two phenomena. He similarly discovered the "principles," of "electromagnetic induction" and diamagnetism, and the laws of electrolysis (interaction between electricity and magnetism). James Clerk Maxwell, brought together electricity, magnetism, and light (relation among electricity, magnetism, and light). Due to some experts, Maxwell Equations (Maxwell Equations, 2016; Maxwell Relations, 2016) for electromagnetic is called the second great "unification" in one science branch after the first one is realized by Mr. Isaac Newton. One can evaluate this unification is of unification of electricity and magnetism, or unification of mathematics and physics for the solution. Or in more general manner, it can be evaluated as unification of mathematics and physics in upper phase (named as mathematical physics), and then unification of electricity and magnetism all together simultaneously. Author re-defined this mathematical physics discipline as one of the hybrid sciences in other work.

Due to some experts, Isaac Newton showed in 1687 that "relationships" like Kepler's would apply in the solar system to a good approximation, as consequences of his own laws of motion and law of universal gravitation. Newton's laws of motion are three physical laws that, together, laid the foundation for classical mechanics. They described the "relationship" between a body and the forces acting upon it, and its motion in response to those forces. Newton showed that these laws of motion, combined with his law of universal gravitation, and explained Kepler's laws of planetary motion. Although some additions, modifications, reformulations made by some other scientists to these kind of theories and laws later, they are continued to be used as an excellent approximations, theories at the border of good/correct transition. Some scientists have informed later that, Mr. Newton and Mr. Maxwell were the most influential scientists with their revolutionary contributions to science, and as influential guides for their studies in some manner.

The "relationship" between "religion and science" (Religion and Science, 2016) has been a subject of study since classical era (8th-7th Century BC), addressed by philosophers, theologians, scientists, and others. 
The kinds of "interactions" that might arise between science and religion categorized, according to a theologian as: (a) Conflict between the disciplines, (b) Independence of the disciplines, (c) Dialogue between the disciplines where they overlap, and (d) Integration of both religion and science into one field. Due to the interaction of religion and science, public acceptance of scientific facts may be influenced by religion; due to the information stated, many in the United States rejected the idea of evolution by natural selection, especially regarding human beings in the past. Nevertheless, the American National Academy of Sciences has written that "the evidence for evolution can be fully compatible with religious faith," a view officially endorsed by many religious denominations globally in that time.

In this work, the author proposed that for some subjects, case-(c) above is important, and for some/most/all subjects case-(d) above is important. Case-(b) above is also meaningful for some research studies, while some situations that can be observed through case-(a) and this will be a guide for the experts to understand the meanings of each discipline separately.

Some experts believed that, disputes between religion and science arise(d) because science and religion are two very different disciplines, and they are based on different foundations according to them: (a) Science is assumed as ultimately based on observation of nature. This is something related with what some people called as science in some manner. Some scientists assume that things happen because of natural causes. Some scientists do/did not believe in the existence of one or more Gods or Goddesses. Others personally believe(d) that one or more deities exist, but assume that he/she/it/they does/do not interfere with nature. Some arguments among scientists are/were existed at the frontiers (limit, border) of each area of science, where new discoveries are being interpreted and discussed because these scientists have/had absence of general/specific information about all other disciplines. (b) Due to some scholars religion is largely based on faith, and the past/present religious groups have/had diverse and often conflicting/differences in beliefs concerning deity, humanity, universe, and other subjects. There are some statements, which considered the following two quotations to indicate the range of beliefs about the conflict and harmony between science and religion until now; "Science is almost totally incompatible with religion" (by Peter Atkins), "There can never be a conflict between true science and true religion, because they both describe reality" (Anon). Author expressed some perspective in other works (Ramiz, 2015; Ramiz, 2016) to guide some people to evaluate religion by using scientific methods, and to evaluate science by using religious methods to understand what is good, bad, incorrect, correct in that perspectives.

The "influences" that "religion has on politics" and the "influences" that "politics has on religion" (Religion and Politics, 2016) focused on the relationship between the subjects of government, political parties, and religious communities until now. This explained through the following basic research areas: (1) All aspects of religious teachings and practices that have direct political contents and messages, such as religious understanding of government, power, political authority, state, political organizing, war, peace, etc.; (2) All aspects of religious behavior and practice that do not have direct political contents and messages but do have direct political consequences, such as building of religious edifices, pilgrimages, etc.; (3) Attitudes and positions of political subjects in the narrow sense towards religion and religious communities, such as that of political parties and groups towards religion and religious communities; (4) Everything is within apparently completely secular public behavior. They have no religious motive that causes religious consequences, such as an economic monopoly achieved by a religious group within a multi-confessional society. This may not but cause political consequences; (5) Religion and international relations; and (6) others. 
These axamples are given to express the sense of "micro interaction" and "macro interaction" in some maner. In general and specific manner, author noticed that some/most of the past/present ideologies, religions, sciences, philosophies do/did not include and/or accept one, or some, or all the other disciplines or sub-inner disciplines of them.

There are some people who define religion and politics as indipendent, religion and science as indipendent, but consider politics and science as dependent.

There are general concepts about "religions and politics" which are adopted by the past/present religions, sects, denominations or beliefs. However, the author put a new point of view to these researches and to these general concepts, and defined ideal political construction for all the world countries (R-Ideology), together with the new defined values, which are related with the 21 dimensions of synthesis, and the related theories, methods, concepts. Some of these values are partly explained here, some others like R-Religion and R-Science are defined by the author more generally and specifically in other work.

\section{Constructional and/or Complementary Theories}

As a result of the R-Synthesis, the author considered more than one theory, which are directly/indirectly related with philosophy and branches of philosophy, to define new philosophy perspective and other subjects. Here, some important three of these theories are considered as constructional and/or complementary references for the definition of the new philosophy perspective and other disciplines. These are: theory of interaction, theory of relation, and theory of hybrid.

As generally/specifically explained in the previous sections, there are different categories of the interaction concept. To be able to understand these theories, simply, it is necessary to evaluate the meaning of these words in good and/or correct way. If the meaning of the word "know" is considered as "to have necessary/exact information," the word "conditional" can be considered as "dependent to condition," and "identify" as "to discover;" "interaction" can be defined as "unconditional/unknown/unidentified and variable effect on each other;" interactions, are unruled, unnamed, unjust effects and limited with number of the possibilities. With this respect, "relation" can be defined as "known dependence/exact dependence/conditional interactions/principal interactions/fixed interactions /fixed conditions on each other, and ruled/named/judicious/continuous," and "hybrid" can be defined as "fixed relations/fixed principles/combined relations/common relations/complementary relations between each other."

Author defined the possible formation stages below in Fig. 1. This figure defines the possible new theories, new disciplines, and in general/specific manner R-Ideology, R-Information, R-Justice/Law, R-Perspectives, R-Philosophy, R-Relations, R-Religion, R-Science, R-Systems, and other disciplines.

Some people proposed that everything is related with others. Author defined that everything is defined as related with each other, and this is because of the consideration of the all possibilities, all subjects, etc.

Author defined that everything can "interact" with each other and there can be interaction for one/some/most/all subjects, but there can be "relation" for none/one/some/most/all possible subjects.

There are/were some people who offered that these everything interacted are/were not coincidence. Author defined theory of interaction, theory of relation, theory of hybrid below to express these possible interactions and possible relations. 


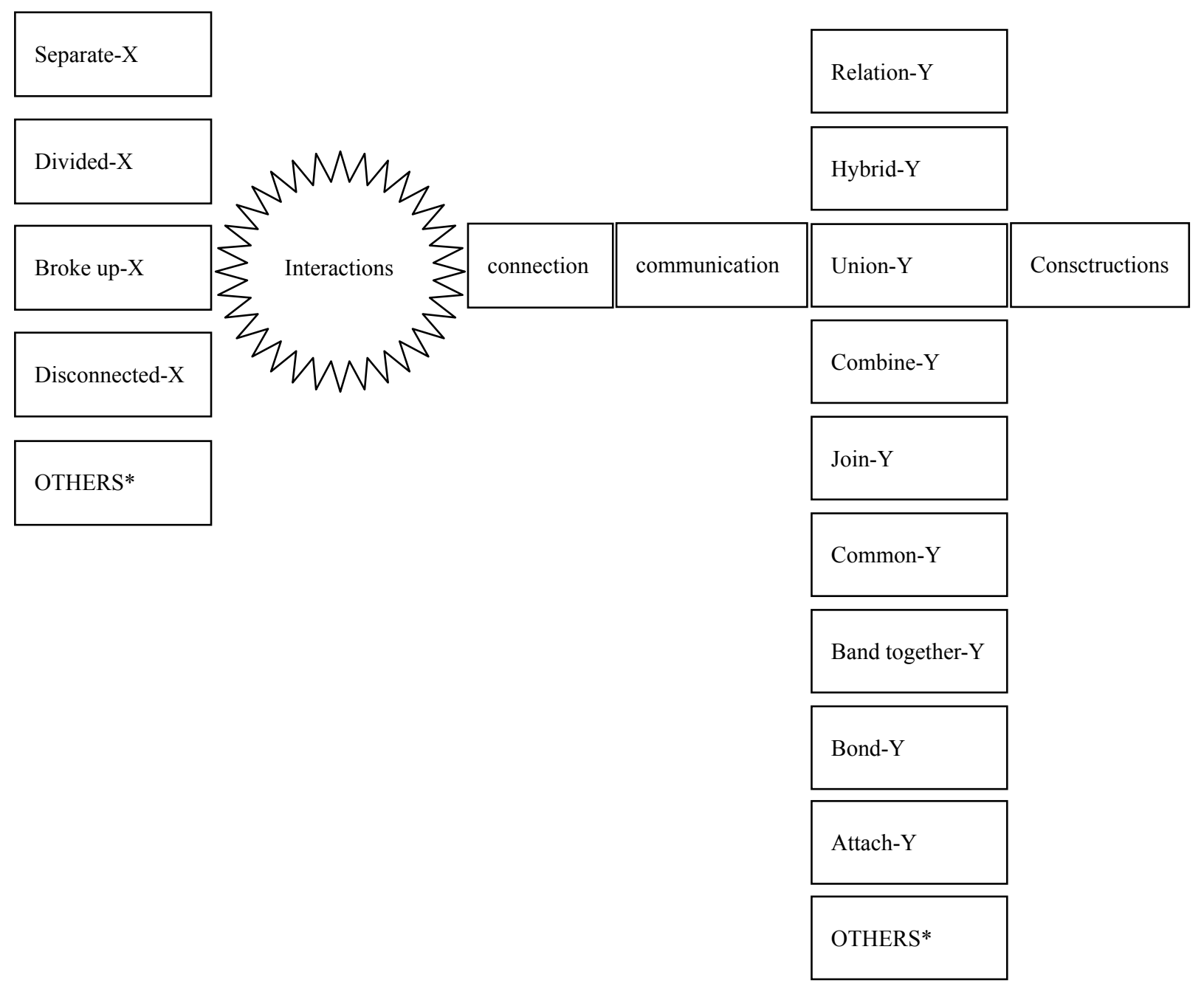

Fig. 1. Possible formation stages (it is not indicating that all the interactions between the two sides will convert to relation/formation between these two sides).

\subsection{Theory of Interaction}

Author defined Theory of Interaction with the following 21 categories to express the related dimension and possible effects of interaction: (1) Interactions due to basic senses; 8-types of interactions; (2) Interaction due to type of effects: (a) constant/static; (i) identified, (ii) unidentified, (b) variable/dynamic; (i) identified, (ii) unidentified, (c) continuous; (i) identified, (ii) unidentified, (d) discontinuous; (i) identified, (ii) unidentified, (e) R-hybrid; (3) Interactions due to disciplines; (a) effective/major/general disciplines, (b) basic disciplines, (c) sub disciplines; (4) Interaction due to effective period; (a) for short period, (b) for mid period, and (c) for long period; (5) Interaction due to energy forms; (6) Interaction due to formality; (a) official, (b) non-official, and (c) R-hybrid; (7) Interaction due to geographical structure considered; (a) territory based, (b) local, (c) country based, (d) regional, (e) transcontinental, (f) worldwide, and (g) universal/cosmos; (8) Interaction due to levels; (9) Interaction due to living forms; (a) bacteriums, (b) plants, (c) animals, (d) human being, (e) other living creatures, (f) aliens, (g) God(s), (h) other living energy forms, (i) other highest living form(s) (GodForm-highest, GodLoyal-2nd, GodPresident-3rd, GodJudge-3rd, GodCommander-3rd, GodProtector-3rd, GodPunisher-3rd); (10) Interaction due to motion; (11) Interaction due to number of sides considered; (a) one, 
(b) two, (c) three or more, (d) some, (e) most, and (f) all; (12) Interaction due to objects/matter; (13) Interaction due to sensitivity; (14) Interaction due to size and/or content; (a) micro interaction, (b) functional interaction, (c) macro interaction; (15) Interactions due to structural categories; (a) basic interactions, (b) hybrid interactions; (16) Interaction due to subjects; (a) for each 37 subjects of services, (b) R-hybrid; (17) Interaction due to system; (18) Interaction due to time; (19) Interaction due to characteristic types; (a) internal, (b) common, (c) mutual, (d) R-hybrid; (20) Interaction due to values; (21) R-Hybrid interaction (yD interactions of previous 20 categories; $y ; 1$ to 20$)$.

Here author defined internal interaction of "some" disciplines as follows, to express the source of some problems noticed during the synthesis: (1) Philosophy; (a) interaction inside the same branch of philosophy and between the sub fields, (b) interaction between the two or more branch of philosophy or sub fields of the branch, (2) Politics; (a) interaction inside the same political ideology and between the political parties, (b) interaction between the two or more different political ideologies or political parties, (3) Religion; (a) interactions inside the same religion and between the denominations, (b) interactions between the two or more different religions or denominations, (4) Science; (a) interaction inside the same science discipline and between branches of this science disciplines, (b) interaction between the two or more different science disciplines, or branches of sciences.

Similarly, author considered mutual interaction between some disciplines as follows, to express some other problems noticed during the R-synthesis: (1) philosophy and politics, (2) philosophy and religion, (3) philosophy and science, (4) politics and religion, (5) politics and science, (6) religion and science, (7) others.

Some of the general/specific interactions gave as follows due to disciplines (in alphabetic order): (a) ideological interaction, (b) philosophical interaction, (c) political interaction, (d) religious interaction, (e) scientific interaction; disciplinary interaction, (f) others.

\subsection{Theory of Relation}

Author defined Theory of Relation with the following 21 categories to express the related dimension and possible effects/results of the relations: (1) Relation due to basic senses, (2) Relation due to type of effects, (3) Relation due to disciplines, (4) Relation due to effective period, (5) Relation due to energy forms, (6) Relation due to formality, (7) Relation due to geographical structure considered, (8) Relation due to levels, (9) Relation due to living forms, (10) Relation due to motion, (11) Relation due to number of sides considered, (12) Relation due to objects/matter, (13) Relation due to sensitivity, (14) Relation due to size and/or content, (15) Relation due to structural categories, (16) Relation due to subjects, (17) Relation due to system, (18) Relation due to time, (19) Relation due to characteristic types, (20) Relation due to values, (21) R-Hybrid relation.

These categories of "relations" are defined as way of solutions to the problems caused by 21 categories of interactions given in previous section in some manner. Some of the general/specific relations due to disciplines are given as follows (in alphabetic order): (i) ideological relation, (ii) disciplinary relation, (iii) personal relation, (iv) philosophical relation, (v) political relation, (vi) religious relation, (vii) scientific relation.

\subsection{Theory of Hybrid}

Author defined Theory of Hybrid with the following 12 categories to express possible effects of hybrid perspective (in alphabetic order): (1) Hybrid due to characteristic types, (2) hybrid due to disciplines - (a) effective/major/general disciplines, (b) basic disciplines, (c) sub disciplines, (3) hybrid due to energy forms, (4) 
hybrid due to formality, (5) hybrid due to interaction, (6) hybrid due to perspective, (7) hybrid due to relation, (8) hybrid due to system, (9) hybrid due to structural categories, (10) hybrid due to subjects; for 37 subjects of services, (11) hybrid due to type of effects, (12) hybrid due to values.

Some of the general/specific hybrid structures due to disciplines are given as follows (in alphabetic order): (i) hybrid ideology, (ii) hybrid philosophy, (iii) hybrid politics, (iv) hybrid religion, (v) hybrid science, (vi) others.

\section{Major Effective Disciplines for a Country and for the World}

Author defined that all of the subjects in the universe can be defined in terms of 10 general dimensions of the universe in general (in alphabetic order): (1) energy forms, (2) interaction types, (3) kinds of interaction, (4) living forms, (5) non-living matters, (6) subjects of interactions, (7) system(s), (8) time, (9) vector space, (10) way of interaction. These are partly explained in some other works (Ramiz, 2015; Ramiz, 2016); some others will be expressed in the future works.

By considering the theory of interaction (as part of R-Interaction), theory of relation (as part of R-Relation), author defined that; all possible "interaction types," "kinds of interaction," "subjects of interaction," "way of interaction" can be used to form "new relations." These relations are fixed, continuable, stable, progressive comparing with the variable, discontinues, instable, corruptible effects of the some/most possible interactions. With this respect, author defined that the following disciplines are major effective disciplines (relations; degree-1) for the living forms in the World (in alphabetic order): (1) R-Administration, (2) R-Basic Senses, (3) R-Continuity, (4) R-Energy forms, (5) R-Ideology, (6) R-Information, (7) R-Justice, (8) R-Living forms, (9) R-Motion/action, (10) R-Non-living matter, (11) R-Philosophy, (12) R-Possibility, (13) R-Religion, (14) R-Science, (15) R-Sensitivity, (16) R-System, (17) R-Time, (18) R-Transformation, (19) R-Uniqueness, (20) R-Values, (21) R-Vector space.

As a result of the synthesis, the author categorized these 21 disciplines (relations) into two groups, Category-A: (1) R-Administration, (2) R-Ideology, (3) R-Information, (4) R-Justice, (5) R-Philosophy, (6) R-Religion, (7) R-Science, (8) R-System, and Category-B: (1) R-Basic Senses, (2) R-Continuity, (3) R-Energy forms, (4) R-Living forms, (5) R-Motion/action, (6) R-Non-living matter, (7) R-Possibility, (8) R-Sensitivity, (9) R-Time, (10) R-Transformation, (11) R-Uniqueness, (12) R-Values, (13) R-Vector space.

These disciplines are important for persons, groups, countries, and for the world. Here, the R-Continuity is defined generally/specifically in other work (Ramiz, April 2016), which includes ideological, philosophical, scientific, religious, and hybrid perspective simultaneously in some manner. R-Ideology is defined generally/specifically in other work (Ramiz, September 2015; Ramiz, April 2016; others). The author evaluated all the possible parameters about the ideology and defined the ideal political construction (Ramiz, 2015; others) and sub ideologies (see related tables; Ramiz, April 2016) as part of R-Ideology. There are 11-constructional methods given to describe R-Ideology specifically. And R-Information (Ramiz, January 2016; here), R-Justice (Ramiz, January 2016; Ramiz, April 2016), R-System (Ramiz, March 2016; Ramiz, April 2016), R-Administration (Ramiz, 2015; Ramiz, 2016; other), R-Religion (Ramiz, March 2016) are defined generally/specifically. These disciplines and others like R-science will be explained more specifically in other works.

Importance of all these disciplines is explained generally/specifically, with effective weight function (Ramiz April 2016), and with other subjects/definitions/figures/systems/tables, which includes ideological, 
philosophical, scientific, religious, and hybrid perspective simultaneously in some manner. This new function is defined to guide some people to understand the importance of the applications of the political/non-political administration systems for the world countries, and to understand the importance of these disciplines, and other perspectives considered due to the 27 definitive/certain case results of the synthesis.

The author defined the "new system" so that R-Administration, R-Ideology, R-Information, R-Justice, R-Philosophy, R-Religion, R-Science, R-System and others (in alphabetic order) are complementary to each other. Also, each of these dimensions/disciplines/concepts/theory includes and/or reflects others. These disciplines include all the subjects/words about administration, about ideology, about information, about justice, about philosophy, about religion, about science, and about system respectively. These disciplines are all integrated into one field. However, this one field is not any of the disciplines of religion, science, ideology, philosophy due to the past known perspective. This field is defined by the author as "to separate and integrate and unify them under one framework." This can better understand with the R-Hybrid perspectives defined by the author, and also by the "good" example of Maxwell equations perspective, and with some other "good" perspectives. The author defined this framework in other work. With this respect, the said disciplines are R-independent in some manner, and they overlap in some other manner. The author defined the new system so that it doesn't include conflicts between these defined disciplines. Author defined ideal political construction (5 to 5 groups), R-Ideology and also R-Religion, R-Science, R-Philosophy, and other definitions, and proposed that all living forms are "related" with R-Religion, R-Science, R-Philosophy, and others. This relation is defined with ideal political construction, new disciplines, New Philosophy perspective, New Era Philosophy, Ideal Philosophical System, and others.

\section{New Perspective of Philosophy}

Author considered his R-synthesis, and as result of the synthesis he noticed that there are more than one way of defining new design, new system, and new perspective of philosophy he proposed, where each way can be used to start from different point to reach the same result(s), together and separately, as unique side of the R-Synthesis. Author explained the new system in other works generally/specifically (Ramiz, 2015; Ramiz, 2016; others). In general manner, it is possible to categorize the perspectives as local, regional, worldwide, universal due to size and content. The word "Philosophy" is defined by the author as R-Philosophy so that it founded its meaning with the complementary basic branches, constructional philosophies, and other branches defined below. As a result of the R-Synthesis, the author noticed that there are definitive, structural, categorical, characteristic (DSCC) problems about the past/present perspective of the philosophy and its branches, where these problems are related and stated with the theory of interaction mentioned above generally/specifically.

When the past/present perspectives about philosophy and branches of philosophy are evaluated, it is noticed that some experts use the following statements to define and/or explain the philosophy and related subjects: "main branches of philosophy," "primary branches of philosophy," "major branches of philosophy," "disciplinary branches of philosophy," "branches of philosophy," "divisions of philosophy," "part of philosophy," "core branches of philosophy."

Other definitive problems are because of the religious perspective of the scholars who define/defined the meaning of the philosophy. If that scholar is/was religious, he/she made the definition of philosophy by considering the God as source, where if scholar is/was non-religious he/she made the definition of philosophy by considering that a human being is the one who is the side/responsible of the philosophy of philosophy. Here, 
it is important to ask the question "philosophy of philosophy of whom," who is the side/responsible of that philosophy of philosophy. Who are the related sides of the philosophy? Author defined that R-Living forms are the side/responsible of philosophy, and philosophy of philosophy. With this respect, it is good and/or correct to consider the followings to understand R-Philosophy; philosophy of person, philosophy of group, philosophy of religion, philosophy of country, philosophy of earth, or philosophy of universe, philosophy of God, and philosophy of highest living form.

Other definitive problems are because of the methodological approaches to the sources, basics, benefits of the philosophy. Philosophy is considered as "love of X," "study of X," "explore of X," "analysis of X" by some experts. Although love of philosophy, love of wisdom can be good for philosophy of person; it is important to consider philosophy and its methodological approach effective for each related subjects to understand the good and/or correct place of philosophy within the new system. This is explained in the following part more specifically. Other definitive problems are because of the differences between the questioning subjects considered for the philosophy. Other definitive, structural, categorical, and/or characteristic problems are: each past/present branch of philosophy has different approach to other branches in general. Some of them are proposed as independent from other branch, or against other branch. Some of them are defined beyond other, or eliminate some or whole part of other, linked to science, or independent from science, different from religion, distinct from science, etc. This is because of the interaction as mentioned above.

As a result of the synthesis, author defined new perspective for the philosophy. There is more than one way to express this new perspective for philosophy, as partly mentioned above. Author expressed some of them below. With this respect, author defined an ideal/standard set of questioning for the philosophy (Q-for-P), and applied it to the philosophy and all related branches of philosophy (Q-for-BP).

\begin{tabular}{|l|l|}
\hline Q-for-P & $\begin{array}{l}\text { definition of philosophy, existence of philosophy, nature of philosophy, knowledge of philosophy, purpose of } \\
\text { philosophy. }\end{array}$ \\
\hline Q-for-BP & $\begin{array}{l}\text { definition of the branch philosophy, existence of branch philosophy, nature of the branch philosophy, } \\
\text { knowledge of branch philosophy, purpose of branch philosophy. }\end{array}$ \\
\hline
\end{tabular}

These two questioning are proposed so that philosophy and branches of philosophy are complementary with each other. However, this complementary relation is formed together with the "philosophy of X," where " $\mathrm{X}$ " is the special subject of the branch philosophy, and also this subject is proposed as good and/or correct discipline. It is noticed that, upon to this discipline, same ideal/standard set of questioning can be considered, but there are some changes/addition within the questioning subjects. Here author defined, new or re-constructed special subjects "X," so that "X" and "philosophy of X" are complementary to each other. Also "philosophy of $\mathrm{X}$ " is related or complementary with "philosophy of Y," and so on. Author believed that, word "philosophy" found its meaning together with these definitions, and the ideal philosophical system, and other subjects defined and expressed below as part of the R-Philosophy. "One word" can consider as the questioning of the all subjects with different dimension in some manner. With this perspective and re-constructions, the number of the "philosophy of X" is limited with "necessary and sufficient" branches of philosophy, where these branches of philosophy are defined to include all subjects. "Philosophy" is a kind of "d-derivative" in front of the "t-variable" (dt), or "grad-operator" which is meaningful together with the "V-variable" (gradV). The deepness/dimension/perspective of the philosophy comes from the "number of the subjects considered in it."

Aim/purpose of R-Philosophy is defined as: Method of understanding, Way of understanding, Theory of understanding, Sense of understanding, Dimension of understanding, and Process of understanding in some 
manner. In more specific manner, R-Philosophy can be define by considering "way of $Y$ " perspective, and due to DSCC perspective as follows (in alphabetic order): (1) way of action, (2) way of administration, (3) way of analysis, (4) way of choose, (5) way of classifying, (6) way of compare, (7) way of communication, (8) way of construction, (9) way of decision, (10) way of defining, (11) way of describing/present, (12) way of design, (13) way of drawing, (14) way of examining, (15) way of explore, (16) way of formation, (17) way of formulation, (18) way of information, (19) way of inspection, (20) way of integration, (21) way of judgment, (22) way of justice, (23) way of life, (24) way of organizing, (25) way of process, (26) way of progress, (27) way of relation, (28) way of representation, (29) way of research, (30) way of rule, (31) way of sensitivity, (32) way of separation, (33) way of solution, (34) way of stability, (35) way of study, (36) way of synthesis, (37) way of teaching, (38) way of transformation, (39) way of understanding, (40) way of unification, (41) way of using, (42) way of wisdom. Aims/purpose of R-Philosophy is defined in general/specific manner as follows due to number of categories " 42 " and subject of disciplines "Y" considered simultaneously; 42 "Methods of Y," 42 "Ways of Y," 42 "Theories of Y," 42 "Sense of Y," 42 "Dimensions of Y," 42 "Process of Y."

To express the DSCC definition and content of R-Philosophy, author considered the above mentioned methods, theories. With this respect, for example, R-Interaction, R-Relation and R-Hybrid theories are considered. By considering the "interaction (int.)" between the Category-A disciplines given above, it is possible to define some important effects, rules, "relations (rel.)" about the disciplines in the world as follows (here " $x D$ " denotes the dimension of interactions, " $x$ " denotes the number of disciplines considered together).

(2D Interactions): (1) Administration Ideology, (2) Administration Information, (3) Administration Justice, (4) Administration Philosophy; philosophy of administration (rel.), (5) Administration $\sim$ Religion, (6) Administration $\sim$ Science, (7) Administration $\sim$ System; administration systems (rel.), system administration (rel.), (8) Ideology Information, (9) Ideology Justice; Ideological justice, judicious ideology, (10) Ideology $\sim$ Philosophy; Philosophy of Politics (rel.), (11) Ideology $\sim$ Religion; Religious Ideology, Ideological Religion, (12) Ideology $\sim$ Science; Political Science (rel.), Scientific Ideology, others, (13) Ideology System; Ideological System, System's Ideology, (14) Information Justice; Sense of Justice (rel.), (15) Information Philosophy; Philosophy of Information (rel.), (16) Information Religion, (17) Information Science; Information Sciences (rel), Scientific Information, (18) Information System; Information Systems, System's Information, (19) Justice $\sim$ Philosophy; Philosophy of Justice (rel.), (20) Justice $\sim$ Religion, (21) Justice Science; Scientific Justice, Justice Sciences, (22) Justice $\sim$ System; Justice systems, System's Justice, (23) Philosophy $\sim$ Religion; Philosophy of Religion (rel.), (24) Philosophy $\sim$ Science; Philosophy of Science (rel.), (25) Philosophy $\sim$ System; Philosophy of System (rel.), (26) Religion $\sim$ Science; Religious Science, Scientific Religion, (27) Religion $\sim$ System, (28) Science $\sim$ System; System Sciences, Scientific Systems.

(3D/4D/5D/6D/7D/8D Interactions): This will give following "relations:" (1) Hybrid Discipline, (2) Hybrid Ideology, (3) Hybrid Information, (4) Hybrid Justice/Law, (5) Hybrid Perspective, (6) Hybrid Philosophy, (7) Hybrid Relation, (8) Hybrid Religion, (9) Hybrid Science, (10) Hybrid System, (11) Hybrid Theory.

By considering the "interaction (int.)" between these Category-B disciplines, or between Category-A and Category-B disciplines, it is possible to define some important effects, rules, relations (rel.), studies, perspectives, doctrines, sciences, fields, branches, etc. as well. Author defined the new branches of philosophy, and/or some reconstructed branches of philosophy in the following sections to express the new perspective of philosophy in more specific manner. 


\section{New Era Philosophy and Ideal Philosophical System}

Author defined New Era Philosophy as a result of the R-synthesis by considering the major effective disciplines, new philosophy perspective, and "xD" interactions given above. With this respect, New Era Philosophy is considered as 8D Hybrid Philosophy, and as a Major Philosophy, for the design, definition, etc., of all the subjects. New Era Philosophy includes "constructional hybrid branches," "sub branches," and "constructional philosophies," which are considered "simultaneously" and given below.

Sub Branches of New Era Philosophy (in alphabetic order): (1) Philosophy of Centrism ${ }^{\circledR}$, (2) Philosophy of Construction $₫($, (3) Philosophy of Creation/Formation $₫($, (4) Philosophy of Definition $\mathbb{R},(5)$ Philosophy of Design $\mathbb{R}$, (6) Philosophy of Dimension $\mathbb{R}$, (7) Philosophy of Effective Weight ${ }^{\circledR}$, (8) Philosophy of GodForm ${ }^{\circledR},(9)$ Philosophy of Integration $\mathbb{}$, (10) Philosophy of Priority $₫$, (11) Philosophy of Process ${ }^{\circledR}$, (12) Philosophy of Progression $\AA \AA$, (13) Philosophy of Relation $₫ \circledR$, (14) Philosophy of Ruling $\mathbb{R}$, (15) Philosophy of Selection $\mathbb{R}$, (16) Philosophy of Separation $\mathbb{R}$, (17) Philosophy of

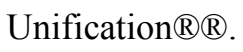

Constructional Philosophies of New Era Philosophy: (1) Philosophy of Basic Senses ${ }^{\circledR}$, (2) Philosophy

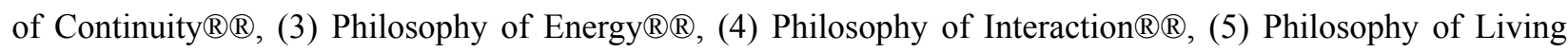
Forms ${ }^{\circledR}$, (6) Philosophy of Matter ${ }^{\circledR}$ C, (7) Philosophy of Motion/Action $®($, (8) Philosophy of Possibility $®$, (9) Philosophy of Sensitivity ${ }^{\circledR}$, (10) Philosophy of Space $\mathbb{C}$, (11) Philosophy of Time ${ }^{\circledR}$, (12) Philosophy of Transformation ${ }^{\circledR}$, (13) Philosophy of Uniqueness $₫ \circledR$, (14) Philosophy of Values ${ }^{\circledR}$.

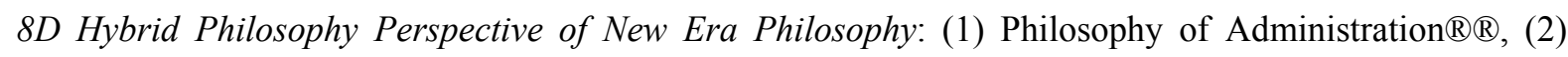
Philosophy of Information ${ }^{\circledR} \mathcal{C}$, (3) Philosophy of Justice ${ }^{\circledR}$, (4) Philosophy of Politics ${ }^{\circledR} \mathcal{C}$, (5) Philosophy of Religion ${ }^{\circledR}$, (6) Philosophy of Science ${ }^{\circledR} \mathcal{C}$, (7) Philosophy of Social Science ${ }^{\circledR}$ C, (8) Philosophy of System ${ }^{\circledR}$. These basic hybrid branches are defined in the following section.

\subsection{Ideal Philosophical System}

As a result of the synthesis, author applied the $27(+)$ definitive/certain result cases of the R-Synthesis to the philosophy discipline, and defined the following branches of R-Philosophy: (1) Branches of R-Philosophy due to structural categories; (a) constructional philosophies, (b) basic branches of philosophy (Basic Philosophies, 1D), (c) hybrid branches of basic philosophies (2D-8D: Hybrid Philosophies), (d) complementary philosophies, (2) Branches of R-Philosophy due to characteristics (subjects); (a) basic branches of philosophy (Basic Philosophies, 1D), (b) sub branches of basic philosophies, (c) sub branches of "xD" hybrid philosophies, (d) Major branch of philosophy (8D-Hybrid Philosophy). These branches are used to form the ideal philosophical system as it is given in the Fig. 2 below. It is important to note that, following definite/certain result cases of the R-Synthesis are applied to the branches of philosophy which are given in the Fig. 2: (1) some subjects added to some branches; (2) the priority of some branches changed; (3) some common branches considered; (4) some branches converged to some subjects; (5) all branches defined under one framework; (6) new branches defined; (7) some branches eliminated; (8) all new and re-constructed are fixed within the framework; (9) values/importance of some branches improved; (10) all branches integrated into the framework; (11) philosophical judgment considered; (12) some branches kept (protected); (13) some branches modified; (14) progression proposed for all branches; (15) some rules put about the branches; (16) some branches re-constructed; (17) some branches re-defined; (18) some branches removed but new branches put instead immediately; (19) philosophical revolution considered; (20) some branches separated; (21) training proposed 
for all branches; (22) some branches unified; (23) some branches united in upper phase; (24) some branches are hybrided; (25) others.

\subsection{New and/or Re-constructed Branches of Philosophy}

With regarding the Fig. 2, author defined the Basic Branches of Philosophy (Basic Philosophies), Hybrid Philosophy and expressed below generally/specifically (in alphabetic order).

\section{(A) Philosophy of Administration $\mathbb{R}$}

Theories of Administration are considered under this philosophy. These theories are proposed basically to have information about: (a) existence of administration, (b) knowledge of administration, (c) nature of administration, (d) sense of administration, (e) purpose of administration; administration of information, administration of justice, administration of political services, administration of religious services, administration of scientific services, administration of systems, others.

Sub Branches: (1) Philosophy of Decision Making ${ }^{\circledR}$, (2) Philosophy of Inspection ${ }^{\circledR}$, (3) Philosophy of Organization ${ }^{\circledR}$, (4) Philosophy of Planning $®$, (5) Philosophy of Security ${ }^{\circledR}$, (6) Philosophy of Stability $®$, (7) Hybrid Sub Branches.

Complementary Branches: (1) Philosophy of Information, (2) Philosophy of Justice, (3) Philosophy of Politics, (4) Philosophy of Religion, (5) Philosophy of Science, (6) Philosophy of Social Science, (7) Philosophy of System.

Constructional Philosophies: (1) Philosophy of Basic Senses, (2) Philosophy of Continuity, (3) Philosophy of Energy, (4) Philosophy of Interaction, (5) Philosophy of Living Forms, (6) Philosophy of Matter, (7) Philosophy of Motion/Action, (8) Philosophy of Possibility, (9) Philosophy of Sensitivity, (10) Philosophy of Space, (11) Philosophy of Time, (12) Philosophy of Transformation, (13) Philosophy of Uniqueness, (14) Philosophy of Values.

\section{(B) Philosophy of Information $\mathbb{B}(\mathbb{C}$}

Theories of Information are considered under this philosophy. These theories are proposed basically to have information about: (a) existence of information, (b) basic principles of information, (c) nature of information, (d) administration of information, (e) inspection of information.

Sub Branches: (1) Methodology, (2) Ethics, (3) Philosophy of Classification $\AA$, (4) Philosophy of

Communication ${ }^{\circledR}$, (5) Philosophy of Economics ${ }^{\circledR} \mathcal{C}$, (6) Philosophy of Education ${ }^{\circledR}$, (7) Philosophy of History ${ }^{\circledR}\left(\mathcal{C}\right.$, (8) Philosophy of Language ${ }^{\circledR} \mathcal{C}$, (9) Philosophy of Mind $\mathbb{}\left(\mathcal{C}\right.$, (10) Philosophy of Statistics ${ }^{\circledR} \mathbb{C}$, (11) Philosophy of Teaching ${ }^{\circledR} \mathcal{C}$, (12) Philosophy of Agreement ${ }^{\circledR}$, (13) Hybrid Sub Branches; Philosophy of Archaeology.

Complementary Branches: (1) Philosophy of Administration, (2) Philosophy of Justice, (3) Philosophy of politics, (4) Philosophy of Religion, (5) Philosophy of Science, (6) Philosophy of Social Science, (7) Philosophy of System.

Constructional Philosophies: (given above). 


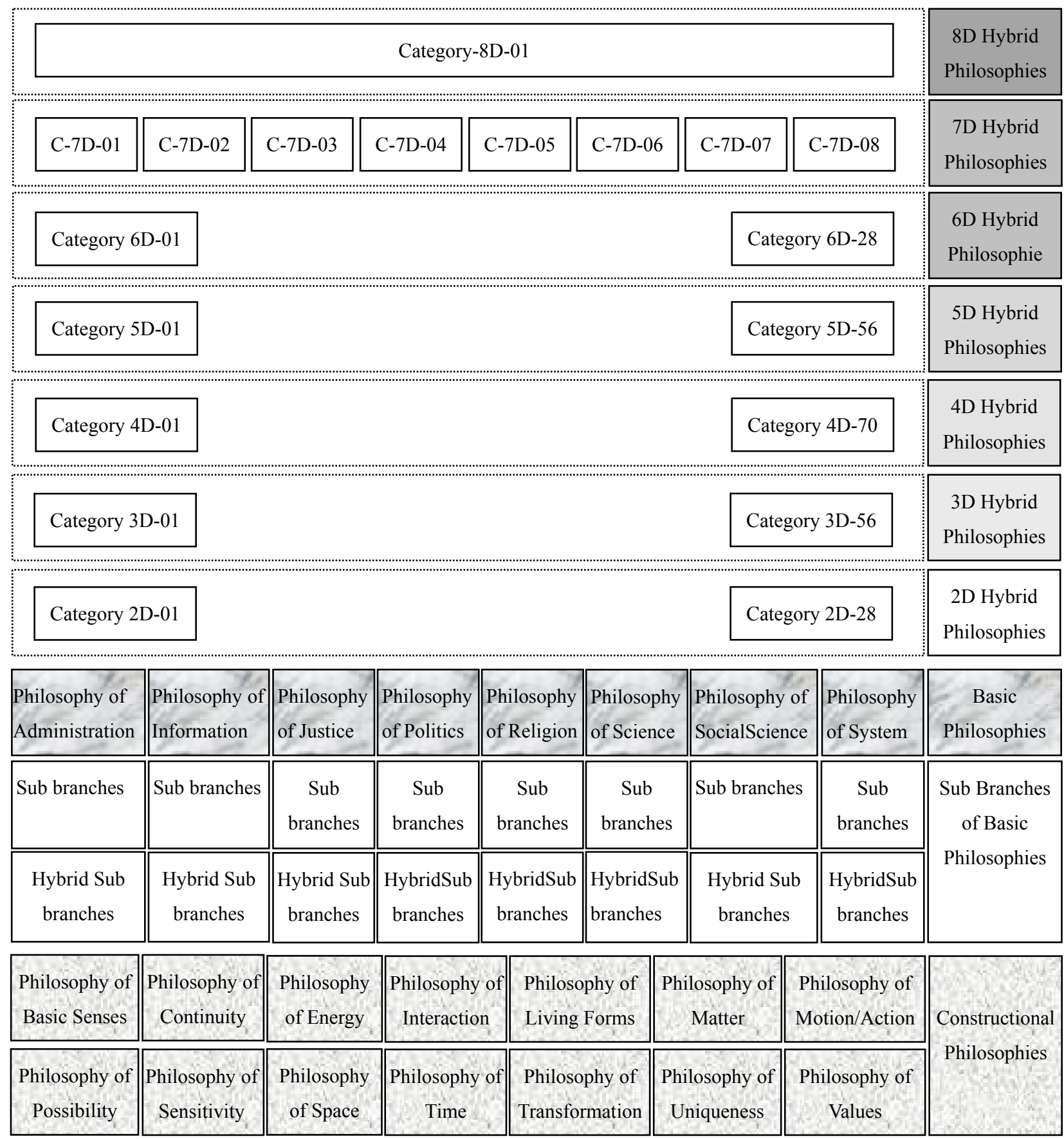

Fig. 2. New ideal philosophical system and branches of philosophy due to structural categories (in alphabetic order).

\section{(C) Philosophy of Justice ${ }^{\circledR}$}

Theories of Justice are considered under this philosophy. These theories are proposed basically to have information about: (a) existence of justice, (b) knowledge of justice, (c) nature of justice, (d) sense of justice, (e) purpose of justice; inspection of administration, inspection of information, inspection of judicial services, inspection of political services, inspection of religious services, inspection of scientific services, inspection of the systems, others. Here, sense of justice is generally/specifically defined in other work (Ramiz, April 2016). 
Sub Branches: (1) Philosophy of Defense ${ }^{\circledR}$, (2) Philosophy of Equivalence ${ }^{\circledR}$, (3) Philosophy of Judgment $\AA^{\circledR}$, (4) Philosophy of Law $®($, (5) Philosophy of Protection $\AA \AA$, (6) Philosophy of Punishment $₫ \circledR$, (7) Philosophy of Rights ${ }^{\circledR},(8)$ Hybrid Sub Branches.

Complementary branches: (1) Philosophy of Administration $₫ \circledR$, (2) Philosophy of Information $₫(,(3)$ Philosophy of Politics ${ }^{\circledR} \mathcal{C}$, (4) Philosophy of Religion ${ }^{\circledR} \mathcal{C}$, (5) Philosophy of Science ${ }^{\circledR}$, (6) Philosophy of Social Science ${ }^{\circledR}\left(\mathcal{C}\right.$, (7) Philosophy of System ${ }^{\circledR} \mathcal{C}$.

Constructional Philosophies: (given above).

(D) Philosophy of Politics ${ }^{\circledR} \subset$

Theories of Politics and Political Ideologies are considered under this philosophy. These theories are proposed basically to have information about: (a) existence of political services, (b) knowledge of political services, (c) nature of political services, (d) purpose of political services, (e) administration of political services, (f) inspection of political services.

Sub Branches: (1) Philosophy of Political services ${ }^{\circledR}$, (2) Philosophy of Political Obligations ${ }^{\circledR},(3)$ Philosophy of Political Power®®, (4) Philosophy of Democracy®®, (5) Philosophy of Political Organizing®®, (6) Hybrid Sub Branches; (a) Philosophy of Political Science*, (b) Philosophy of Political Construction ${ }^{\circledR}$ (s5D), (c) Philosophy of Political Administration ${ }^{\circledR} \circledR($ s5D).

Complementary Branches: (1) Philosophy of Administration, (2) Philosophy of Information, (3) Philosophy of Justice, (4) Philosophy of Religion, (5) Philosophy of Science, (6) Philosophy of Social Science, (7) Philosophy of System.

Constructional Philosophies: (given above).

(E) Philosophy of Religion $\mathbb{}(\mathbb{C}$

Theories of Religion are considered under this philosophy. These theories are proposed basically to have information about: (a) existence of God, (b) knowledge of God, (c) nature of God.

Theories: (a) New Era Theory (R-Religion; New Era Religion), (b) Theism, (c) non-theism

Complementary Branches: (1) Philosophy of Administration, (2) Philosophy of Information, (3) Philosophy of Justice, (4) Philosophy of Politics, (5) Philosophy of Science, (6) Philosophy of Social Science, (7) Philosophy of System.

Constructional Philosophies: (given above).

(F) Philosophy of Science $\mathbb{\circledR}(\mathrm{C}$

Theories of Science are considered under this philosophy. These theories are proposed basically to have information about: (a) existence of science, (b) knowledge of science, (c) nature of science, (d) Purpose of science.

Sub Branches ${ }^{\circledR \mathcal{C}}$ : (1) Philosophy of biology, (2) Philosophy of chemistry, (3) Philosophy of electromagnetic $(\AA$, (4) Philosophy of mathematics, (5) Philosophy of physics, (6) Hybrid Sub Branches; (a) Philosophy of Medicine ${ }^{\circledR} \mathcal{C}$, (b) Others (defined in other work).

Complementary Branches: (1) Philosophy of Administration, (2) Philosophy of Information, (3) Philosophy of Justice, (4) Philosophy of Politics, (5) Philosophy of Religion, (6) Philosophy of Social Science, (7) Philosophy of System.

Constructional Philosophies: (given above).

This philosophy branch, its relation with sciences, and branches of sciences are explained in other work. 


\section{(G) Philosophy of Social Science ${ }^{\circledR(C}$}

Theories of Social Science are considered under this philosophy. These theories are proposed basically to have information about: (a) existence of social values, (b) knowledge of social values, (c) nature of social values, (d) Purpose of social values.

Complementary Branches: (1) Philosophy of Administration, (2) Philosophy of Information, (3) Philosophy of Justice, (4) Philosophy of Politics, (5) Philosophy of Religion, (6) Philosophy of Science, (7) Philosophy of System.

Constructional Philosophies: (given above).

The relation between this philosophy branch and sciences and branches of sciences are explained generally below. Here social sciences* are re-constructed based on the concept given with the words "social" and "sciences." With this respect, social sciences* are considered as follows: (a) anthropology, (b) area studies, (c) beauty and art, (d) culture and art, (e) dance, (f) demography, (g) ethnic and cultural studies, (h) film, (i) gender and sexuality studies, (j) geography (human), (k) linguistics, (l) love and relations, (m) music, (n) pedagogy, (o) psychology, (p) sociology, (q) social works, (r) sports, (s) theatre.

Here, archaeology*, economics*, history* are took out of social sciences*, and considered inside the Philosophy of Information ${ }^{\circledR}()_{\text {, as }}$, more significant disciplines. Criminology* is considered as out of social sciences*. Law* (Law, 2015) is considered as out of social sciences*, and inside Philosophy of Justice $\mathbb{R}$. Political science* (Political Science, 2015) is considered as out of social sciences*, and considered inside the Philosophy of Politics. International relations* is considered as out of social sciences*. Some of these are explained in other works.

\section{(H) Philosophy of System ${ }^{\circledR C}$}

Theories of system are considered under this philosophy. These theories are proposed basically to have information about: (a) existence of system, (b) knowledge of system, (c) nature of system, (d) purpose of system.

Sub Branches: (1) Philosophies due to administration systems ${ }^{\circledR}$, (2) Philosophies due to information systems ${ }^{\circledR}\left(\right.$, (3) Philosophies due to justice systems ${ }^{\circledR} \AA$, (4) Philosophies due to political systems $\mathbb{R}$, (5) Philosophies due to religious systems ${ }^{\circledR}$, (6) Philosophies due to scientific systems ${ }^{\circledR}$, (7) Philosophies due to hybrid systems ${ }^{\circledR}$.

Complementary Branches: (1) Philosophy of Administration, (2) Philosophy of Information, (3) Philosophy of Justice, (4) Philosophy of Politics, (5) Philosophy of Religion, (6) Philosophy of Science, (7) Philosophy of Social Science.

Constructional Philosophies: (given above).

\section{(I) Hybrid Philosophy ${ }^{\circledR}$}

Hybrid Theories are considered under this philosophy. These theories are proposed basically to have information about: (a) existence of hybrid structure, (b) knowledge of hybrid structure, (c) nature of hybrid structure, (d) purpose of hybrid structure.

Here, the dimension of hybrid philosophy $(\mathrm{xD})$ is defined with the number of the basic philosophy considered together among the 8 basic philosophies. Here, each of the "xD" Hybrid philosophy defines and includes a new philosophy perspective as follows: (1) 8D Hybrid philosophy, (2) 7D Hybrid philosophies, (3) 6D Hybrid philosophies, (4) 5D Hybrid philosophies, (5) 4D Hybrid philosophies, (6) 3D Hybrid philosophies, 
(7) 2D Hybrid philosophies. These new " $\mathrm{xD}$ " hybrid philosophy perspectives are categorized as follows (Fig. 2); Category 2D-xx: denotes 28 Categories for 2D Hybrid Philosophies, for example, Category 2D-01: It is a hybrid philosophy that consider two of basic hybrid branches of "Philosophy of Administration" and "Philosophy of Information," and so on; Category 3D-xx: denotes 56 Categories for 3D Hybrid Philosophies; Category 4D-xx: denotes 70 Categories for 4D Hybrid Philosophies; Category 5D-xx: denotes 56 Categories for 5D Hybrid Philosophies; Category 6D-xx: denotes 28 Categories for 6D Hybrid Philosophies; Category 7D-xx: denotes 7 Categories for 7D Hybrid Philosophies; Category 8D-01: only 1 Category for 8D Hybrid Philosophy.

Basic Philosophies: (1) Philosophy of Administration $\AA \AA$, (2) Philosophy of Information $\mathbb{C}$, (3) Philosophy of Justice $\mathbb{R}$, (4) Philosophy of Politics ${ }^{\circledR}$ C, (5) Philosophy of Religion $\mathbb{C}$, (6) Philosophy of Science ${ }^{\circledR} \mathcal{C}$, (7) Philosophy of Social Science ${ }^{\circledR} \mathcal{C}$, (8) Philosophy of System $®($.

Constructional Philosophies: (given above).

Author defined science of administration, science of information, science of justice, science of politics, sciences, science of system, hybrid sciences in other work as related to the philosophy and its branches.

The content, effectiveness, value, levels, significance, meaning, and/or weight of the past, present philosophy branches are re-constructed/re-defined, or new defined due to $27(+)$ definitive/certain result cases of the R-Synthesis. Some of the functional measures are increased and strengthened together with the new defined basic philosophies, sub branches, and constructional philosophies.

Here, R-Philosophy is defined as: New Era Philosophy, Hybrid Philosophy, constructional philosophy, basic philosophy, branches of philosophy and all of the subjects related with philosophy. R-Philosophy is including the starting, process, and obtaining product in some manner.

\section{Integration of the Past/Present Branches into the Ideal Philosophical System}

Author evaluated generally/specifically the past/present branches of philosophy* (Branches of Philosophy, 2016) due to the subjects they are considered. As a result of this, author integrated these past/present branches of philosophy* into the ideal philosophical system (Fig. 2). It is important to note that these new positions/levels are related with the new defined/re-defined/re-constructed branches of philosophy®@ . Some of these branches* are given below; some others are defined under the new branches ${ }^{\circledR} \subset$ given in the previous section. Here $\left(^{*}\right)$ denotes that these branches are considered as they are defined in the past.

Metaphysics* is proposed related with the C-5D category hybrid philosophy (Fig. 2). This C-5D hybrid category includes: Philosophy of Information ${ }^{\circledR} \mathcal{C}$, Philosophy of Religion ${ }^{\circledR} \mathcal{C}$, Philosophy of Science ${ }^{\circledR}$, Philosophy of Social Science ${ }^{\circledR}\left(\mathcal{C}\right.$, and Philosophy of System ${ }^{\circledR}(\mathcal{C}$ together.

Logic* is proposed as related with the C-2D category hybrid philosophy (Fig. 2). This hybrid category includes Philosophy of Information and Philosophy of Science together.

Ethics* is proposed as related with the Philosophy of Information (Fig. 2).

Epistemology* is proposed as related with the C-2D category hybrid philosophy (Fig. 2). This hybrid category includes Philosophy of Information AND Philosophy of Science together.

Aesthetics* is proposed as related with the Philosophy of Social Science $($ (Fig. 2).

Ontology* is proposed as related with the constructional philosophy $\mathbb{}(\mathcal{C}$, and it is considered as related with Philosophy of living forms ${ }^{\circledR}(\mathcal{C}$ (Fig. 2). 
Philosophy of space and time* is proposed as related with the constructional philosophy $\mathbb{C}$, and it is considered as two separate constructional branches; Philosophy of Space $\mathbb{\complement}$ C, and Philosophy of Time $\mathbb{C}$ (Fig. 2).

Philosophy of human nature* is proposed as related with the constructional philosophy, and it is considered as related with Philosophy of Living Forms (Fig. 2).

\section{Philosophical Interests of the Some Past Philosophers}

Author defined the major effective disciplines and new perspective of the philosophy in the previous sections first, then evaluated the general/specific philosophical interests of the 384 past philosophers. Due to this evaluation, author noticed that only some of the philosophers considered more than one philosophy branch* at the same time. The philosophers who considered more than one philosophy branch* given below specifically (Table 1).

When the philosophers of history* were generally/specifically evaluated, author noticed that only 9 of the philosophers of history among 42 philosopher were interested in with more than one philosophy branch*.

When the philosophers of law* were generally/specifically evaluated, author noticed that only few of them considered $4 / 5$ philosophy branches* at the same time. Some of them were legal philosophers; some of them were professors; some of them considered law and politics at the same time. Only one of them acted as strong non-religious and did not accept natural law. Some of them considered the metaphysics*; some of them were theologian, and some of them used ethics*. Few of them defined new theories regarding the philosophy of law*, one of whom considered some science sub disciplines beside the law. One of them considered science and technology studies, while some others were not interested in philosophy of religion* and/or philosophy of politics*. With this respect, the R-Synthesis is a kind of synthesis of the two theories in some manner: one that supports natural law, and the one that does not support natural law.

Author determined that, some of the philosophers of religion* were effective because of they were interested in with multi-branches* at the same time, as shown in Table 1 below. Beside this, author noticed that some of these philosophers were theologian, or religious responsible (archbishop, hakham, monk, rabbi), or scholar. While some others adopted some religions such as Catholic, Islam, Judaism, Lutheran, Orthodox, Protestant (in alphabetic order), only few of them were also economist; some of them cared about ethics*; some few of them considered political theory; some others were professor as well; some others considered epistemology*; some others were engineer; and only one of them was king beside being philosopher. When the philosophers of science* were generally/specially evaluated, author noticed that some of the philosophers of science (13 of 55+) considered more than one philosophy branch* at the same time as shown in Table 1 below. Some others were interested in physics; some others considered mathematics also, while some of them being pioneer of a branch of scientific revolution. Some of them related with astronomy, one of whom was bishop; some of them defined their new scientific theories; some others were not interested in philosophy of religion* and philosophy of politics*; some of them were interested in metaphysics*; some of them were inventors; and so on. It is important to notice that only few of the influential political philosophers* had science and religion mentality beside politics to succeed influential jobs in politic arena. However, there are some few persons who worked on politics bases but also considered religion and engineering mentality together. Only few of them were interested in with multi branches as in Table 1 below. Only one of them considered Christianity, Islamism, and Judaism philosophy together. Some of them involved with teaching as professor. 
Some of them considered the political ethics, and only some few of them considered philosophy of politics*, philosophy of religion*, and philosophy of science* at the same time. Only one person considered philosophy of mind*, political philosophy*, philosophy of religion*. Some of them being political president of the country, some of them being effective politician, and some of them defined new political ideologies, and so on.

Table 1

Some of the Philosophers and Their Philosophical Interests (due to Date of Birth)

\begin{tabular}{|c|c|c|c|c|c|c|c|}
\hline \multicolumn{8}{|c|}{ Philosophical Interests of Philosophers (in alphabetic order) } \\
\hline $\begin{array}{l}\text { Pioneer/Founder } \\
\text { People }\end{array}$ & $\begin{array}{l}\text { Philosophy of } \\
\text { History* }\end{array}$ & $\begin{array}{l}\text { Philosophy of } \\
\text { Politics* }\end{array}$ & $\begin{array}{l}\text { Philosophy of } \mathrm{H} \\
\text { Religion* }\end{array}$ & $\begin{array}{l}\text { Philosophy of } \\
\text { Science* }\end{array}$ & Ethics* & Others & Life Period \\
\hline Confucius & & $\mathrm{X}$ & $\mathrm{X}$ & & $\mathrm{X}$ & $\mathrm{X}$ & $551 \mathrm{BC}-479 \mathrm{BC}$ \\
\hline Plato & $\mathrm{X}$ & $\mathrm{X}$ & $\mathrm{X}$ & $\mathrm{X}$ & $\mathrm{X}$ & $E^{*}, X$ & 428BC-348BC \\
\hline Aristotle & & $\mathrm{X}$ & $\mathrm{X}$ & $\mathrm{X}$ & $\mathrm{X}$ & M, L, PoL, PoM, X & 384BC-322BC \\
\hline Alhazen & & & & $\mathrm{X}$ & & $\mathrm{X}$ & $965-1040$ \\
\hline Al-Ghazali & & & & & & $\mathrm{L}^{*}, \mathrm{PoL}^{*}$ & $1058-1111$ \\
\hline Thomas Aquinas & $\mathrm{X}$ & $\mathrm{X}$ & $\mathrm{X}$ & & $X$ & $\mathrm{PoL}^{*}, \mathrm{PoM}^{*}, \mathrm{X}$ & $1225-1274$ \\
\hline Niccolò Machiavelli & $X$ & & & & $\mathrm{X}$ & $\mathrm{X}$ & $1469-1527$ \\
\hline Francisco de Vitoria & & $\mathrm{X}$ & & & & PoL* & $1483-1546$ \\
\hline Galileo Galilei & & & & $\mathrm{X}$ & & $\mathrm{X}$ & $1564-1642$ \\
\hline Thomas Hobbes & & $\mathrm{X}$ & & & $X$ & PoL*, & $1588-1679$ \\
\hline René Descartes & & & & $\mathrm{X}$ & & $E^{*}, M^{*}, \operatorname{PoM}^{*}, X$ & $1596-1650$ \\
\hline Baruch Spinoza & & $\mathrm{X}$ & $\mathrm{X}$ & & $\mathrm{X}$ & PoM* $^{*}, \mathrm{X}$ & $1632-1677$ \\
\hline Isaac Newton & & & & $\mathrm{X}$ & & $\mathrm{X}$ & $1642-1726$ \\
\hline G.W. von Leibniz & $\mathrm{X}$ & & & & $\mathrm{X}$ & $\mathrm{M}^{*}, \mathrm{~L}^{*}, \mathrm{PoM}^{*}, \mathrm{X}$ & $1646-1716$ \\
\hline David Hume & & $\mathrm{X}$ & $\mathrm{X}$ & $\mathrm{X}$ & $\mathrm{X}$ & E, M, PoL, PoM, X & $1711-1776$ \\
\hline Jean-J. Rousseau & $\mathrm{X}$ & $\mathrm{X}$ & & & & $\mathrm{X}$ & $1712-1778$ \\
\hline Immanuel Kant & $\mathrm{X}$ & $\mathrm{X}$ & $\mathrm{X}$ & $\mathrm{X}$ & $\mathrm{X}$ & $\mathrm{E}^{*}, \mathrm{M}^{*}, \mathrm{PoL}^{*}, \mathrm{X}$ & $1724-1804$ \\
\hline G.W.Friedrich Hegel & $\mathrm{X}$ & $\mathrm{X}$ & $\mathrm{X}$ & & $\mathrm{X}$ & $\mathrm{A}^{*}, \mathrm{~L}^{*}, \mathrm{X}$ & $1770-1831$ \\
\hline Auguste Comte & $\mathrm{X}$ & & & $\mathrm{X}$ & & $\mathrm{X}$ & $1798-1857$ \\
\hline John Stuart Mill & & $\mathrm{X}$ & & $\mathrm{X}$ & $\mathrm{X}$ & PoL*, X & $1806-1873$ \\
\hline Karl Marx & $\mathrm{X}$ & $\mathrm{X}$ & $\mathrm{X}$ & & & $\mathrm{X}$ & $1818-1883$ \\
\hline F.Wilhelm Nietzsche & $\mathrm{X}$ & $\mathrm{X}$ & $\mathrm{X}$ & & $X$ & $A^{*}, M^{*}, O^{*}, X$ & $1844-1900$ \\
\hline Albert Einstein & & & & $\mathrm{X}$ & & $\mathrm{X}$ & $1879-1955$ \\
\hline Friedrich Hayek & & $\mathrm{X}$ & & & & PoM* $^{*}, \mathrm{X}$ & $1899-1992$ \\
\hline Ernest Nagel & & & & $\mathrm{X}$ & & $\mathrm{PoM}^{*}, \mathrm{X}$ & 1901-1985 \\
\hline Sir Karl R. Popper & $\mathrm{X}$ & $\mathrm{X}$ & & $\mathrm{X}$ & & $E^{*}, M^{*}, \mathrm{PoM}^{*}, \mathrm{X}$ & 1902-1994 \\
\hline Gilles Deleuze & $X$ & & & & & $\mathrm{~A}^{*}, \mathrm{M}^{*}, \mathrm{MP}^{*}, \mathrm{X}$ & $1925-1995$ \\
\hline Michel Foucault & $X$ & $\mathrm{X}$ & & & $\mathrm{X}$ & $\mathrm{E}^{*}, \mathrm{PoT}^{*}, \mathrm{PoLi}^{*}, \mathrm{x}$ & 1926-1984 \\
\hline Hilary W. Putnam & & & & $\mathrm{X}$ & & $\mathrm{E}^{*}, \mathrm{PoM}^{*}, \mathrm{X}$ & $1926-2016$ \\
\hline
\end{tabular}

Note: Italic words indicate that these philosophers are interested in more than one philosophy branch* at the same time; $(*)$ denotes that these branches are defined due to past philosophical branch perspectives; Here A*: Aesthetics, $E^{*}$ : Epistemology, $L^{*}$ : Logic, M*: Metaphysics, MP*: Meta-Philosophy, O*: Ontology, PoL*: Philosophy of Law, PoLi*: Philosophy of Literature, PoM*: Philosophy of Mind, PoT*: Philosophy of Technology, X: some other sciences.

There was another political person who is not in the list of the influential political philosophers named as Benjamin Franklin (1706-1790). He was also a special type of politician, who was leading author, printer, 
political theorist, politician, diplomat, activist, civic states man, postmaster, scientist and also an inventor on electricity, lightning rod, bifocals at the same time. There are some other "good" examples for politic persons who considered some "good" subjects as professional interests.

Author evaluated philosophical interests of these past philosophers, generally/specifically, and noticed that being a political philosopher or interested in with another one philosophy branches is not enough for the solution of the some/most/all problems. As a result of the evaluation of these philosophical interests, it is possible to define that only some of the philosophers' philosophical "interests" can be considered as "related" with the new 2D, 3D, or 4D category of Hybrid Philosophy (Fig. 2).

\section{Conclusion}

Author considered new R-Synthesis as a method for the evaluation of the all subjects about philosophy and branches of philosophy, and for the solution of the related problems. Author expressed some results of the new synthesis in this article. With this respect, author explained the general perspective, scope/period/content of the all subjects, dimension, and definitive/certain result cases of the new synthesis. Past/present perspectives about philosophy* and branches of philosophy* are expressed. Author explained philosophy, generally/specifically, due to historical period, due to religious perspective, due to its organized categories/branches or areas, and some of the interactions considered between the disciplines by some experts. As a result of the R-Synthesis, the author defined constructional and/or complementary theories. Theory of interaction, theory of relation, and hybrid theory defined and explained generally/specifically. Major effective disciplines are defined for a country and for the world. With this respect, author defined that the following disciplines are major effective disciplines (relations; degree-1) for the living forms (in alphabetic order): (1) R-Administration, (2) R-Basic Senses, (3) R-Continuity, (4) R-Energy forms, (5) R-Ideology, (6) R-Information, (7) R-Justice, (8) R-Living forms, (9) R-Motion/action, (10) R-Non-living matter, (11) R-Philosophy, (12) R-Possibility, (13) R-Religion, (14) R-Science, (15) R-Sensitivity, (16) R-System, (17) R-Time, (18) R-Transformation, (19) R-Uniqueness, (20) R-Values, (21) R-Vector space. Author defined some of these disciplines more generally and specifically in other articles. Here, new perspective of philosophy is defined. New Era Philosophy, Ideal Philosophical System, and new and/or re-constructed branches of philosophy are defined. Integration of the past/present branches of philosophy into the ideal philosophical system is expressed generally/specifically. Philosophical interests of the some past philosophers are given. Some references are given as cited works at the last section to guide some people to understand the general/specific meaning of the related subjects. Author applied the new philosophy perspective to the past/present systems, by considering the contents and results of the R-synthesis, and defined the following theories, administration system(s), sense of justice, and others for the world countries and for the world to express the effective use of the new philosophy perspective for some practical realizations: (a) Continuable political administration system for world countries (Ramiz, 2015; Ramiz, January 2016), (b) countries' union and political/non-political administration systems for the world countries (Ramiz, March 2016), (c) new administration systems for the world countries and sense of justice \& continuity in the system administration (Ramiz, April 2016), (d) good and/or correct perspective that must be behind administration(s) (Ramiz, March 2016), (e) others.

Author defined the good and/or correct perspective that must be behind the definition of philosophy and branches of philosophy in this article. This work is also good and/or correct guide to explain the purpose of R-Philosophy for a world country and/or for the world. 


\section{Works Cited}

Aesthetics. Wikipedia. $<$ https://en.wikipedia.org/wiki/Aesthetics>. 2016, June.

Aesthetics. Internet Encylopedia of Philosophy. $<$ http://www.iep.utm.edu/aestheti/>. 2016, June.

Aesthetics. Britannica. $<$ http://global.britannica.com/topic/aesthetics $>$. 2016, June.

Branch of Philosophy of Science. Philosophy Basics. <http://www.philosophybasics.com/branch_philosophy_of_science.html>. 2016, March.

Branches of Social Science. Wikipedia. <https://en.wikipedia.org/wiki/Category:Social_sciences>. 2016, March.

Branches of Philosophy. Wikibooks. <https://en.wikibooks.org/wiki/Introduction_to_Philosophy/The_Branches_of_Philosophy>. 2016, March.

Branches of Philosophy. Metaphysics for Life. <http://www.metaphysics-for-life.com/branches-of-philosophy.html>. 2016, March.

Branches of Philosophy. Slide Share. <http://www.slideshare.net/boylente/branches-of-philosophy-23487292>. 2016, March.

Branches of Philosophy. Theological Studies.

$<$ http://theologicalstudies.org/resource-library/philosophy-dictionary/85-5-branches-of-philosophy>. 2016, March.

Branches of Philosophy. Importance of Philosophy. <http://www.importanceofphilosophy.com/FiveBranchesMain.html>. 2016, March.

Bucaille, M. The Bible, the Qur'an and Science: The Holy Scriptures Examined in the Light of Modern Knowledge, book, Trans. Mondial by Editions Seghers, Paris, The Socialist People's Libyan Arab Jamahiriya, Tripoli. 1973.

Categories of Philosophy. Ro Angelo.

$<$ http://www.roangelo.net/logwitt/philosophy-origin.html\#Stoics-and-Aristotle-categories-of-philosophy>. 2016, March.

Crotty, W. J., Freeman, D. M., and Gatlin, D. S. Political Parties and Political Behavior. Boston: Allyn and Bacon, 1971.

Epistemology. Utm University. $<$ http://www.iep.utm.edu/epistemo/>. 2016, March.

Epistemology. Carm. <https://carm.org/dictionary-epistemology>. 2016, March.

Epistemology. Oxford Dictionaries. <http://www.oxforddictionaries.com/definition/english/epistemology>. 2016, March.

Epistemology. Philosophy Basics. $<$ http://www.philosophybasics.com/branch_epistemology.html>. 2016, March.

Epistemology. Routledge. $<\mathrm{https}: / /$ www.rep.routledge.com/articles/epistemology/v-2>. 2016, March.

Epistemology. Stanford University. $<$ http://plato.stanford.edu/entries/epistemology/>. 2016, March.

Ethics. Wikipedia. <https://en.wikipedia.org/wiki/Ethics>. 2016, March.

Ethics. Internet Encylopedia of Philosophy. $<\mathrm{http} / / /$ www.iep.utm.edu/ethics $>$. 2016, March.

Ethnic Groups. Wikipedia. $<$ https://en.wikipedia.org/wiki/List_of_contemporary_ethnic_groups $>$. 2015, October.

Ethnic Groups. The World Factbook. <https://www.cia.gov/library/publications/the-world-factbook/fields/2075.html>. n.d.

Federation. Wikipedia. <https://en.wikipedia.org/wiki/Federation>. 2016, March.

Feynman, R. P., Leighton, R. B., and Sands, M. The Feynman Lectures on Physics Vol. 1, Chaps. 1, 2, \& 3. 1964.

Feynman, R. P. Mathematical Formulation of the Quantum Theory of Electromagnetic Interaction. Lancaster and New York: American Physical Society, 1950. Physical Review 80 (3): 440-57. Bibcode:1950PhRv...80..440F. doi:10.1103/PhysRev.80.440.

Feynman, R. Wikipedia. $<$ https://en.wikipedia.org/wiki/Richard_Feynman>. March, 2016.

Gülaltay, S. T. Tanrı'nın Türkleri (Turks of God). Kafkas, 2005.

History of Economic Thought. Wikipedia.<https://en.wikipedia.org/wiki/History_of_economic_thought>. 2015, June.

History of Philosophy. Wikipedia. $<$ https://en.wikipedia.org/wiki/Philosophy\#General_history>. 2016, June.

History of Religions. Wikipedia. $<$ https://en.wikipedia.org/wiki/History_of_religions $>$. 2010, May.

History of Science. Wikipedia. <https://en.wikipedia.org/wiki/History_of_science>. 2015, May.

Ideology. Wikipedia. $<$ https://en.wikipedia.org/wiki/Ideology>. 2015, October.

Influential Political Philosophers. Wikipedia. $<$ https://en.wikipedia.org/wiki/Philosophy_of_Politics>. 2015, August.

Information. Stanford University (SU). <http://plato.stanford.edu/entries/information/>. 2016, March.

Kepler Laws. Wikipedia. $<$ https://en.wikipedia.org/wiki/Kepler\%27s_laws_of_planetary_motion>. 2015, August.

Law. Wikipedia. $<$ https://en.wikipedia.org/wiki/Law>. 2015, October.

List of Legal Systems. Wikipedia. $<$ https://en.wikipedia.org/wiki/List_of_national_legal_systems\#Hybrid_law>. 2015, June.

List of Ethicists. Wikipedia. $<$ https://en.wikipedia.org/wiki/List_of_ethicists>. 2016, March.

List of Mythologies. Wikipedia. <https://en.wikipedia.org/wiki/List_of_mythologies>. 2015, June.

List of Philosophers. Wikipedia. <https://en.wikipedia.org/wiki/Lists_of_philosophers>. 2016, June. 
List of Philosophers of Mind. Wikipedia. <https://en.wikipedia.org/wiki/List_of_philosophers_of_mind>. 2015, August.

List of Philosophers of Religion. Wikipedia. $<$ https://en.wikipedia.org/wiki/List_of_philosophers_of_religion>. 2015, August.

List of Philosophers of Science. Wikipedia. <https://en.wikipedia.org/wiki/List_of_philosophers_of_science>. 2015, August.

List of Philosophies. Wikipedia. $<$ https://en.wikipedia.org/wiki/List_of_philosophies>. 2016, March.

List of Political Ideologies. Wikipedia. <https://en.wikipedia.org/wiki/List_of_political_ideologies>. 2010, May.

List of Religions. Wikipedia. $<$ https://en.wikipedia.org/wiki/List_of_religions_and_spiritual_traditions>. 2015, August.

Logic. Wikipedia. <https://en.wikipedia.org/wiki/Logic>. 2016, June.

Lord, A. R. The Principles of Politics: An Introduction to the Study of the Evolution of Political Ideas. Oxford: Clarendon Press, 1931.

Major Branches of Philosophy. Stanford University. $<$ http://plato.stanford.edu/search/search?page=17\&query=Major Branches of Philosophy\&prepend=None>. 2016, March.

Maxwell Equations. Wikipedia. $<$ https://en.wikipedia.org/wiki/Maxwell\%27s_equations>. March, 2016.

Maxwell Relations. Wikipedia. $<$ https://en.wikipedia.org/wiki/Maxwell_relations>. March, 2016.

Mayor, F. and Forti, A. Bilim ve Iktidar (Science and Political Power). çev. M. Küçük, TÜBITTAK, 2000.

Metaphysics. Wikipedia. <https://en.wikipedia.org/wiki/Metaphysics>. 2016, June.

Metaphysics. Stanford Encyclopedia of Philosophy. <http://plato.stanford.edu/entries/metaphysics>. 2016, June.

Metaphilosophy. Wikipedia. <https://en.wikipedia.org/wiki/Metaphilosophy>. 2016, March.

Metaphilosophy. Internet Encylopedia of Philosophy. <http://www.iep.utm.edu/con-meta/\#SH1b>. 2016, March.

Neibuhr, R. and Sigmund, P. E. The Democratic Experience: Past and Prospects. Praeger, 1969.

Newton Laws. Wikipedia. $<$ https://en.wikipedia.org/wiki/Newton\%27s_laws_of_motion>. 2015, August.

Notable Philosophers of Law. Wikipedia. <https://en.wikipedia.org/wiki/Philosophy_of_law>. 2015, August.

Ogden, C. K. and Richards, I. A. The Meaning of Meaning. London: Routledge \& Kegan Paul, 1956.

Online Encyclopedias. Wikipedia. $<$ https://en.wikipedia.org/wiki/List_of_online_encyclopedias $>$. 2015, May.

Oersted, H. Christian. NNDB. <http://www.nndb.com/people/341/000104029/>. 2016, July.

Ørsted, H. Christian. Wikipedia. <https://en.wikipedia.org/wiki/Hans_Christian_\%C3\%98rsted >. 2016, July.

Outline of Academic Disciplines. Wikipedia. $<$ https://en.wikipedia.org/wiki/Outline_of_academic_disciplines\#Philosophy>.

Outline of Philosophy. Wikipedia. <https://en.wikipedia.org/wiki/Outline_of_philosophy>. 2016, March.

Philosophers of History. Wikipedia. $<$ https://en.wikipedia.org/wiki/Philosophy_of_history>. 2015, August.

Philosophers of Mind. Wikipedia. <https://en.wikipedia.org/wiki/List_of_philosophers_of_mind>. 2015, August.

Philosophers of Science. Wikipedia. $<$ https://en.wikipedia.org/wiki/Philosophy_of_science>. 2015, August.

Philosophy. Wikipedia. $<$ https://en.wikipedia.org/wiki/Philosophy>. 2015, October.

Philosophy. Berkley University. <http://undsci.berkeley.edu/article/philosophy>. 2016, March.

Philosophy. Conservapedia. <http://www.conservapedia.com/Philosophy>. 2016, March.

Philosophy. Florida State University (FSU). <http://philosophy.fsu.edu/content/view/full/36588>. 2016, March.

Philosophy. Internet Encyclopedia of Philosophy. $<$ http://www.iep.utm.edu/p/>. 2016, March.

Philosophy. Learnnc. $<$ http://www.learnnc.org/lp/editions/philosophy-resources/7646>. 2016, March.

Philosophy. Philosophy Basics. <http://www.philosophybasics.com/branch_logic.html>. 2016, March.

Philosophy. Philosophy Religion. < http://www.philosophy-religion.org/living/philosophy/1.pdf $>$. 2016, March.

Philosophy. Roangelo. $<$ http://www.roangelo.net/logwitt/philosophy-origin.html>. 2016, March.

Philosophy. Space and Motion. <http://www.spaceandmotion.com/Philosophy.htm>. 2016, March.

Philosophy of History. Wikipedia. < https://en.wikipedia.org/wiki/Philosophy_of_history>. 2015, June.

Philosophy of Information. Wikipedia. $<$ https://en.wikipedia.org/wiki/Philosophy_of_information>.

Philosophy of Law. Wikipedia. <https://en.wikipedia.org/wiki/Philosophy_of_law>. 2015, August.

Philosophy of Mind. Wikipedia. <https://en.wikipedia.org/wiki/Philosophy_of_mind>. 2015, August.

Philosophy of Politics. Wikipedia. <https://en.wikipedia.org/wiki/Philosophy_of_Politics>. 2015, October.

Philosophy of Religion. Wikipedia. <https://en.wikipedia.org/wiki/Philosophy_of_religion>. 2015, October.

Philosophy of Science. Wikipedia. $<$ https://en.wikipedia.org/wiki/Philosophy_of_science>. 2015, August.

Philosophy of Science. Internet Encyclopedia of Philosophy. <http://www.iep.utm.edu/category/s-1-m/science/>. 2016, March.

Political Philosophers. Wikipedia. $<$ https://en.wikipedia.org/wiki/Political_philosophers $>$. 2015, August.

Politics. Wikipedia. $<$ https://en.wikipedia.org/wiki/Politics>. 2015, June.

Political Engineering. Wikipedia. $<$ https://en.wikipedia.org/wiki/Political_engineering>. 2015, October. 
Political History. Wikipedia. <https://en.wikipedia.org/wiki/Political_history>. 2015, June.

Political Ideologies. Wikipedia. <https://en.wikipedia.org/wiki/Political_ideology>. 2015, October.

Political Religion. Wikipedia. $<$ https://en.wikipedia.org/wiki/Political_religion>. 2016, February.

Political Science. Wikipedia. $<$ https://en.wikipedia.org/wiki/Political_science>. 2015, October.

Political Spectrum. Wikipedia. $<$ https://en.wikipedia.org/wiki/Political_spectrum>. 2015, October.

Political Systems. Wikipedia. $<$ https://en.wikipedia.org/wiki/Political_system>. 2015, October.

Progressivism. Wikipedia. $<$ https://en.wikipedia.org/wiki/Progressivism. 2015, May.

Ramiz, R. "A Continuable Political Administration System for World Countries-I." International Relations and Diplomacy 3.9 (September 2015): 609-24.

Ramiz, R. “A Continuable Political Administration System for World Countries-II.” International Relations and Diplomacy 4.1 (January 2016): 14-37.

Ramiz, R. "Countries' Union and Political/Non-political Administration Systems for the World Countries." International Relations and Diplomacy 4.3 (March 2016): 139-76.

Ramiz, R. "New Administration Systems for the World Countries and Sense of Justice \& Continuity in the System Administration." International Relations and Diplomacy 4.4 (April 2016): 219-60.

Religion. Wikipedia. <https://en.wikipedia.org/wiki/Religions>. 2015, October.

Religion and Mythology. Wikipedia.<https://en.wikipedia.org/wiki/Religion_and_mythology>. 2016, February.

Religion and Politics. Internet Encyclopedia of philosophy. <http://www.iep.utm.edu/rel-poli/>. 2016, March.

Religion and Politics. Wikipedia. <https://en.wikipedia.org/wiki/Religion_and_politics>. August, 2015.

Religion and Science. Wikipedia. $<$ https://en.wikipedia.org/wiki/Relationship_between_religion_and_science>. 2016, March.

Religion and Science. Christianity. $<$ http://www.christianity.co.nz/science4.htm>. 2016, March.

Religion and Science. Stanford University. $<$ http://plato.stanford.edu/entries/religion-science/>. 2016, March.

Religion and Science. Religious Tolerance. $<\mathrm{http}: / /$ www.religioustolerance.org/sci_rel.htm>. 2016, March.

Religion and Science. Reform Judaism. <http://www.reformjudaism.org/science-religion-better-world>. 2016, March.

Religion and Science. Wikipedia. $<$ https://en.wikipedia.org/wiki/Religion_and_science $>$. August, 2015.

Religion and Science. Stanford Encyclopedia of Philosophy. $<$ http://plato.stanford.edu/entries/religion-science/>. 2016, February.

Religious Books and Texts. Wikipedia. <https://en.wikipedia.org/wiki/Holy_books>. 2015, August.

Religious Science. Wikipedia. <https://en.wikipedia.org/wiki/Religious_Science>. 2016, March.

Resnik, D. B. Bilim Etiği (The Ethics of Science: An Introduction). çev. V. Mutlu, Ayrıntı, 2004.

Science. Wikipedia. $<$ https://en.wikipedia.org/wiki/Science>. 2015, May.

Science and Religion. Reasonable Faith. <http://www.reasonablefaith.org/what-is-the-relation-between-science-and-religion>. 2016, March.

Science and Religion. Berkley University. <http://undsci.berkeley.edu/article/science_religion>. 2016, March.

Science and Religion. In Science and Religion Today. <http:/www.scienceandreligiontoday.com/>. 2016, March.

Science and Religion. Religious Tolerance. <http://www.religioustolerance.org/scirel_ov1.htm>. 2016, March.

Scientific Revolution. Wikipedia. <https://en.wikipedia.org/wiki/Scientific_revolution>. 2015, August.

Separation of Powers. Wikipedia. $<$ https://en.wikipedia.org/wiki/Separation_of_powers>. 2015, May.

Social. Wikipedia. $<$ https://en.wikipedia.org/wiki/Social>. 2016, March.

Social Science. Wikipedia. $<$ https://en.wikipedia.org/wiki/Social_science>. 2015, October.

Social Science. Britannica. $<$ http://global.britannica.com/topic/social-science>. 2016, March.

Space. Wikipedia. $<$ https://en.wikipedia.org/wiki/Space>. 2016, March.

Synthesis. Wikipedia. $<$ https://en.wikipedia.org/wiki/Synthesis>. 2015, August.

System. Wikipedia. $<$ https://en.wikipedia.org/wiki/System>. 2015, September.

Yücel, T. Türk ve Dünya Tarihi Ansiklopedisi (Turkish and World History Encyclopedia). çev., Gelişim-Hachette, Le Livre de Paris, S. N. C., Biblioclub de France, 1985. 